\title{
LANDSCAPE TRANFORMATION OF SMALL RURAL SETTLEMENTS WITH DISPERSED TYPE OF SETTLEMENT IN SLOVAKIA
}

\author{
František Petrovičํㅜ, Lucia Petrikovičová2
}

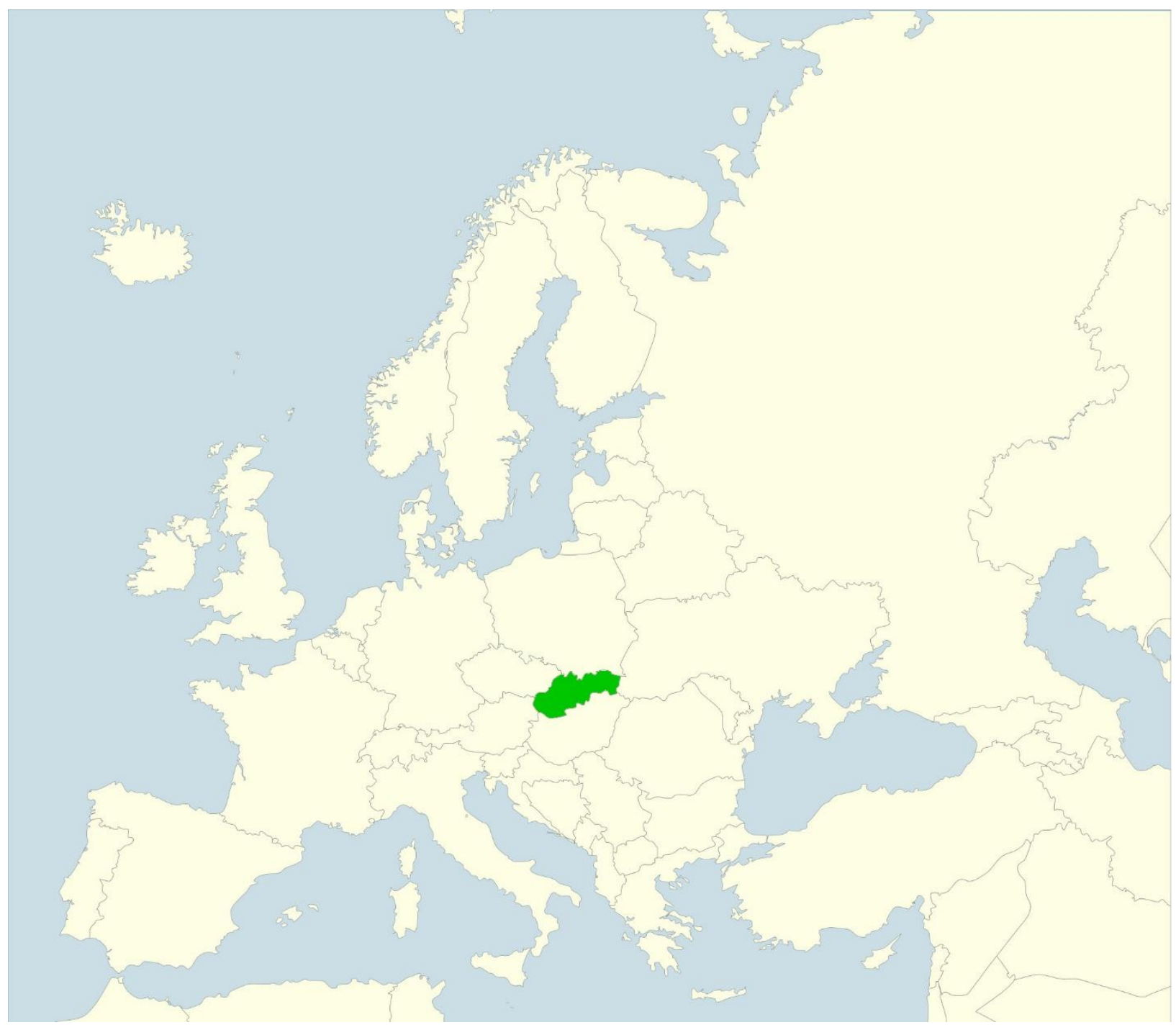

${ }^{1}$ Prof. RNDr. František Petrovič, PhD., Faculty of Natural Sciences, Constantine the Philosopher University in Nitra, Slovakia, e-mail: fpetrovic@ukf.sk, ORCID: 0000-0002-2364-3610

${ }^{2}$ RNDr. Lucia Petrikovičová, PhD., Faculty of Natural Sciences, Constantine the Philosopher University in Nitra, e-mail: Ipetrikovicova@ukf.sk, ORCID: 0000-0002-3200-794X 
Abstract: In this paper we will focus on one of the five areas of dispersed settlement in Slovakia - Novobanská štálová area and the forecast of its development on the example of selected characteristics (household income and its use, population). The analysis of historical development by using historical maps can relatively and accurately locate areas with permanently low intensity of use and areas that have fulfilled a stabilizing function in the cultural landscape throughout the observed development. At the same time, based on the analysis of the historical development of settlements, we can interpret the trend of the development of land use in the future. The originality of this type of landscape with a dispersed type of settlement also in the sense of the European Landscape Convention lies in its limited occurrence. Besides Slovakia, it occurs only in the Czechia and especially on the Czech-Slovak border. The analysis of demographic characteristics of selected municipalities also indicates qualitative and quantitative changes leading to the gradual extinction of the territory. The presented area as a part of small dispersed settlement has some unique cultural, historical and natural values, which are a reflection of human life and activities in difficult mountain conditions.

Súhrn: $\quad$ V príspevku sa zameriame na jednu z piatich oblastí rozptýleného osídlenia na Slovensku - Novobanskú štálovú oblast' a prognózu jej vývoja na príklade vybraných charakteristík (domový fond a jeho využívanie, počet obyvatel'ov). Analýza historického vývoja dovoluje rozlišit' a s využitým historických máp pomerne presne lokalizovat' plochy s trvalo nízkou intenzitou využívania a plochy, ktoré po celú dobu sledovaného vývoja plnili stabilizačnú funkciu v kultúrnej krajine. Zároveň na základe analýzy historického vývoja osídlenia môžeme interpretovat' trend vývoja využívania krajiny aj do budúcnosti. Originalita takéhoto typu krajiny s disperzným typom osídlenia aj $v$ zmysle Európskeho dohovoru o krajine spočíva $v$ jeho obmedzenom výskyte. Okrem Slovenska sa vyskytuje len v Česku a to hlavne na česko-slovenskom pohraničí. Analýza demografických charakteristík vybraných obcí však indikuje kvalitatívne a kvantitatívne zmeny vedúce až k postupnému vymretiu územia. Prezentované územie ako súčast' štálovej oblasti má niektoré svojrázne kultúrne, historické a prírodné hodnoty, ktoré sú odrazom života a aktivít človeka v náročných horských podmienkach.

Key words: dispersed settlement, land use, cultural heritage, rural landscape, second home

Klúčové slová: rozptýlené osídlenie, využitie zeme, kultúrne dedičstvo, vidiecka krajina, druhé bývanie

\section{Highlights:}

- The rural agricultural landscape is an important part of our cultural heritage, especially that part of it in which historic landscape structures are preserved

- This type of ancient settlement and related land management forms are endangered, so it is really important to pay attention tothis fact

- Dispersed settlement remains roughly in its original shape and form, but no longer fulfills its primary function - housing

- Analysis of demographic characteristics of the surveyed municipalities indicates qualitative and quantitative changes, leading to the gradual extinction of the territory 


\section{Introduction}

Historical and current way of land use and secondary landscape structure tells us a lot about the economic and social situation of the local community, but also of the whole society. The study of the development of land use, in turn, reflects the way in which society copes with socio-political influences, resp. changes. Agricultural mountain landscape is compared to lowland country more dependent on human input into the agro-ecosystems. Extreme natural conditions are associated with marginality.

One of the few preserved historical landscape structures in Slovakia is "Kopaničiarske" (in the literature, scattered or dispersed settlement is often used as a synonym). In accordance with the European Landscape Convention (2020), the aim of the Slovak Republic is also to identify and define the types of countries with regard to their special values. Just such a specific type of landscape, Slovakia is a rural area with a dispersed form of settlement. It is a preserved archetype of the landscape (Hreško et al. 2015).

Dispersed settlement is not only specific in Slovakia (Huba, 1988, 1990, Lauko, 1985, Petrovič, 2006), it also occurs in other countries such as in Scandinavia Norling (1960), Hansen (1972), in Bulgaria Hoffman (1964), in Africa Stone (1991), Donaldson, Boshoff (2001), in Czechia Löw, Míchal (2003), Št'astná, Vaishar (2020), Vaishar, Št'astná (2019), resp. in US Barnes, Robinson (1940), however, its total area is minimal for the size of these countries. The uniqueness of this type of landscape lies in its limited occurrence.

In the context of changing the preferences of selected population groups, there is great potential for this settlement for second homes. The use of buildings for recreation and second homes has a long tradition in Slovakia in the form of cottages. From the end of the 1990s, new trends in second homes, which have been operating abroad for several decades, began to manifest themselves here as well. One of these trends is the construction of new holiday homes in attractive locations, such as mountain areas, spas, locations near water surfaces, or golf courses. In our studied area, however, it is more of a reconstruction of the original buildings, which are part of the historic landscape structure. The second type of housing is specific in that it is a site which is not as attractive as such mountain areas or areas close to the water. Although we follow the upward trend of interest in recreation facilities that the seasonal housing may also become permanent housing. The current Covid crisis also helps with this trend, as many Slovaks are looking for a quiet, peaceful and isolated location where they could spend time with their family. This fact is very closely related to national tourism, which now become larger dimensions.

Type of living in the Czechia and Slovakia are paid by Fialová, Vágner (2014), they focused in particular on the construction of new apartment buildings, villages and so on. They also focused on the possible negatives of the construction of new recreational apartments. They claim that the reasons for the construction are mainly related to the inspiration in alpine projects and the efforts of developers to make a profit. This construction strengthens the impacts of traditional tourism and at the same time creates specific problems to this type of construction. Uncontrolled construction can have negative impacts on the surrounding natural and landscape environment, the economic situation of the village and can also affect the social atmosphere in the village. The concept of timeshare as an alternative to apartment recreational apartments and "Dutch holiday villages" is addressed by Fialová, Kadlecová, Nožičková (2011). Vágner, Fiaová (2011) focused on the influence of second housing on the formation of regional identity in regions with an important recreational function. Thus, several publications point to the current development of the issue of second homes and its impact on the population and the region.

\section{Theoretical backround}

Globalization is taking place in the world, leading to the creation of a uniform society and, more or less, to the loss of the specificity of regions. This is gradually reflected in the creation and visual characteristics of the landscape and settlements. Gradually, the settlements are transformed into homogeneous units to which services are linked. Subsequently, marginal settlements, which in the past had agricultural and production functions, disappear. In the paper we focus on land use changes of such areas with a specific dispersed settlements in Slovakia. 


\subsection{What is dispersed settlement and how was it created}

Dispersed ("kopaničiarske", "štálové", "laznícke") settlement in Slovakia is one of the specific manifestations of socio-economic activities, conditional specific natural and historical conditions. It was created as a product of historically youngest colonization waves in Slovakia and its genesis was very diverse. The term "kopanica" understand group irregularly scattered settlements in different shapes of terrain. As the name itself reveals "kopanice" - it is soil, which essentially is the way that people get culturing previously farm land respectively they had been cultivated uninhabited land (Huba, 1988, 1989, 1990).

Verešík (1974) divides the areas of dispersed settlement of Slovakia into:

1. Myjavsko-bielokarpatská area (myjavská a trenčianska subarea)

2. Javornícko-kysucká area (kysucká, žilinská, považskobystrická, oravská)

3. Area of „kopanice“ in Strážovské mts. (Valašská Belá, Čavoj)

4. Stredoslovenská štálová area

5. Area of Slovenské Rudohoria mts. and Krupinská planina (podpolianska, krupinská, lučenská, rimavsko-sobotská and breznianska)

The origin of these dispersed settlements goes back far earlier, in the middle Ages when the area belonged to the Hungarian Kingdom. Beyond pastoralism, this settlement type is also the result of mining activities.

Similar internal colonization except Hungary and in other monarchies took place in the $15^{\text {th }}-16^{\text {th }}$ century (Etkind, 2013).

In modern history, such "resettlement" of the territory occurred after World War II. It was the inhabitants of Slovakia who settled the displaced areas of the Czech border in Czechoslovakia after the displaced inhabitants to Germany (Vaishar, Nosková, Nováková, 2019; Vaishar, Dvořák, Nosková, Zapletalová, 2017).

The forming of dispersed settlements in Slovakia related to the three colonization waves wallachian, highlander (both were shepherds) and the "kopaničiarska":

Wallachian colonization meant that were settled mountainous areas of northern and central Slovakia by pastoral settlers especially in the $15^{\text {th }}$ and $17^{\text {th }}$ century, but also hit the mountainous region surrounding countries - Ukraine, Poland, Transylvania and Moravia. The first mention of the wallachian colonization in Slovakia comes from the first half of the $12^{\text {th }}$ century (Chaloupecký, 1947). In the initial phase of wallachian colonization in the $13^{\text {th }}-14^{\text {th }}$ century, a small group of pastoral population of Romanian and Ukrainian ethnicity (pastors) came to the east of Slovakia. These successive waves of settlement by the inhabitants of the nomadic way of life (mostly sheep farmers) were influenced by the political situation (Cojocaru, 2014). Incentive to migration of pastors were the Tatar invasion and later the Turkish people in Romania Principalities of Wallachia and Moldavia. There was thus internal colonization within the Kingdom of Hungary, where the native population of these areas were leaving the north of the potentially military conflict and because of the different religiosity as progressive Ottoman Empire (Sisestean, 2012). In the 15th century, in its handling of the west, is the bearer of wallachian colonization, which already happened home Slovak population, possibly Polish and Ukrainian from neighboring areas. "Wallachian", it remained only in the manner of his employment by cattle and sheep grazing use high altitude alpine meadows (alpine meadow - "pol'any") and grassland forest. Wallachian colonization spread in the northern parts of Zemplín, Šariš, Spiš, Orava and Trenčín county, in central Slovakia spread in part of Gemer and Horehronie. Wallachian communities in these areas based on the so-called shepherding rights, which was only adapted by german ("šoltýska") law, was suited to the needs of the new pastoral settlers.

Highland colonization is younger, falls within the $17^{\text {th }}-18^{\text {th }}$ century. Mountaineers inhabited mainly territory on the upper Kysuca, upper Orava and northern part of Spiš.

Kopaničiarska colonization meant internal settlement of mountain Slovakian regions by native population in $16^{\text {th }}-19^{\text {th }}$ century. Establishment of "kopaničiarske" settlements was associated with 
a large number of land that was the nursery areas of difficult access. Therefore, the remote "kopanice" built seasonal dwellings and farm buildings, which later became the basis of permanent settlements. Their creation is simultaneously addressed, the issue of overpopulation feudal holdings in parent communities. It was a purely agricultural colonization with secondary character (by dividing family property residents of concentrated settlements (cores) in mountain and hill areas). Peaked at $18^{\text {th }}$ and in the first half of the $19^{\text {th }}$ century, when the most of dispersed settlements was created. Through this colonization, settlements in Kysuce and Orava, Detva, Malé and Biele Carpathian Mountains, Pohronský Inovec, Tribeč and Vtáčnik, originated.

\begin{abstract}
"Kopanice", which resulting in $18^{\text {th }}$ and in the first half of the $19^{\text {th }}$ century remained a special category of land. Feudal laws from that period to regulate deposition on soil of landowners serfs and feudal benefit from this land, but the "kopanice" were not covered. "Kopanice" remain the exclusive property of the landlord, part of the landlord "family" land. While communal forest land was subject under the law in hereditary use, thus landlord, it could not freely indulge serf, with "kopanice" landlord to dispose freely and determine from them any benefits, etc. Neither Terezian landowners did not bring in that direction more severe changes. Just fixed the conditions under which a landowner may revoke "kopanice" from the holder. It was to do with the precise definition of compensation for users of "kopanice" for the work involved in cultivating them.
\end{abstract}

Hromádka (1943), Verešík (1974) and Varšík (1985) specifically earmarked colonization in Myjavská hill lands. Relatively, isolated and concealed position of Myjavská highlands played a positive role in the 16th century. Protected by walls of the Malé Carpathians became a refuge for people fleeing from southern Slovakia from the Turkish raids. The inflow of residents fleeing from the Turks, caused a relative overpopulation in the villages, which was the basis for "kopaničiarska" colonization.

\title{
2.2 Current state of „kopanice“
}

At the time of the census in 1869 (Retrospektivní lexikon obcí Československé socialistické republiky 1850-1970, 1978), the network of Kopaničiarie municipalities was practically completed. Only in the extremely large, embossed or asymmetrically populated cadastres of the „kopaničiarske“ municipalities, even after 1869, the new municipalities became independent. This process culminated in the 1950s in connection with the new administrative and economic division of the territory. The collectivization of agriculture after 1948 negatively affected most areas with dispersed settlements (with the exception of the area around the Hrinová municipality). Although they have not been fully affected (larger home gardens remained), the plots /parcels were merged in the beginning and subsequently, as there was more demanding mechanization to change arable land to grasslands. Gradually, the main function self-supply disappeared (pictures 1,2,3,4,5,6, 7, 8, 9, 10). At present, the recreational function of these areas is beginning to predominate. Most new municipalities in that period were separated from the original problematic cadastre Myjava and other new independent dispersed municipalities were established in the western part of Kysucká and the northern part of the Lučenecká subregion (Huba, 1989). The first mentions of the number of Kopaničiarske villages are given by Janšák (1929), when he identified 132 of them with 2,176 Kopanice. In 1961, there were 166 Kopaničiarske municipalities in Slovakia with 2,899 Kopanice (a residential unit in an outbuilding with at least 2 houses) on an area of $4,640 \mathrm{~km}^{2}$ (Sitár, 1967), which represented $9.46 \%$ of the territory of Slovakia. The increase in the number of dispersed municipalities and kopanice can be explained by the inaccurate allocation in 1929 and not by the creation of new municipalities. At present, the creation of new dispersed settlements is basically unrealistic, and certainly not in terms of the need for new agricultural land. Rather, there is a tendency to decline, respectively. their extinction (Spišiak, 1998).

Data on the current overall state of „kopanice“ are not known, some authors deal with individual municipalities resp. groups of municipalities (Belčáková et al. 2021, Huba 1986, 1989; Lauko 1985, 1990; Petrovič 2004, 2005, Petrovič, Muchová 2013, Šolcová, 2008ab) but complete areas of dispersed settlement have not been studied since 1961.

It was this factor that influenced the aim of our research. In this paper we will focus on one of the five main areas of dispersed settlement in Slovakia - the Novobanská Štálová area and 
the forecast of its development on the example of selected characteristics (housing stock and its use, population).

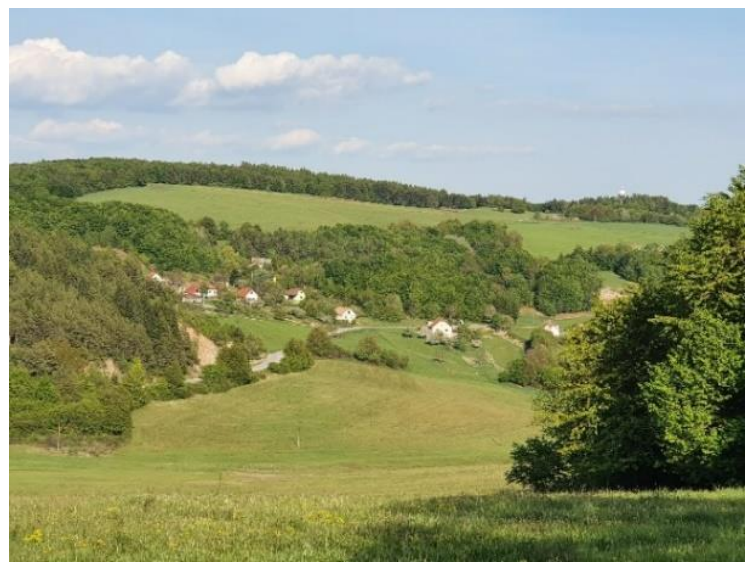

Fig 1. Malá Lehota - Zimmermanov štál

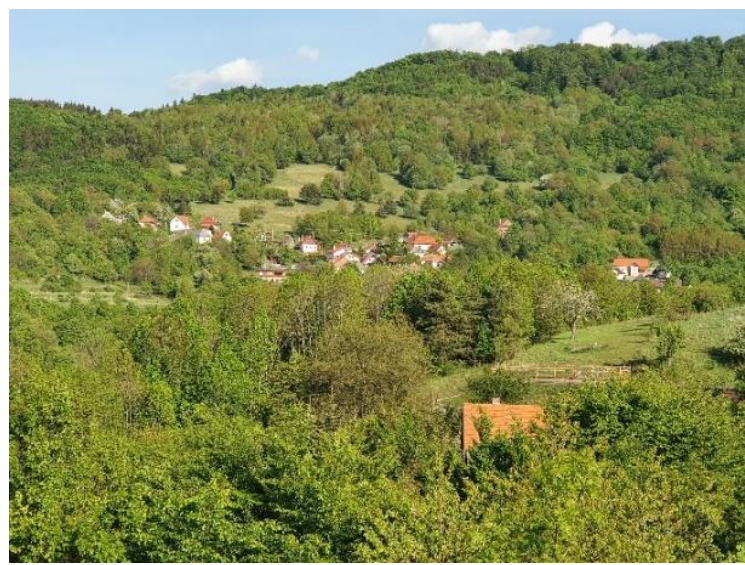

Fig 3. Malá Lehota - Hubačov štál

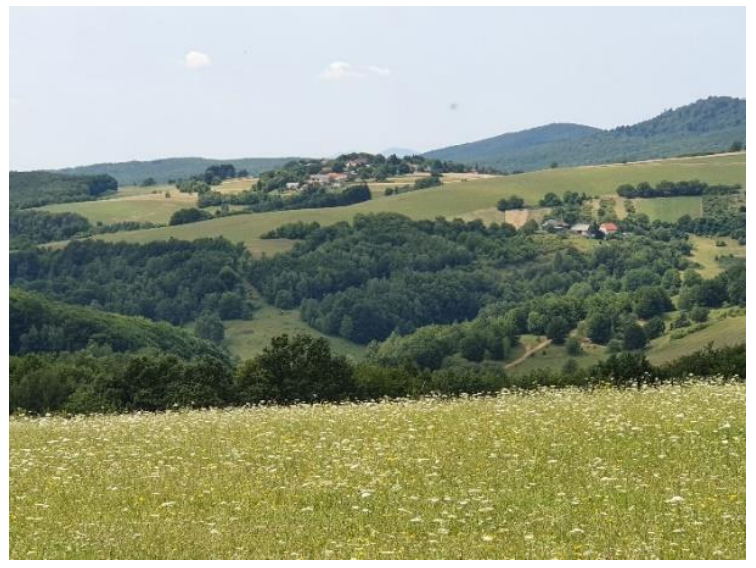

Fig 5. Malá Lehota - Rajnohov štál

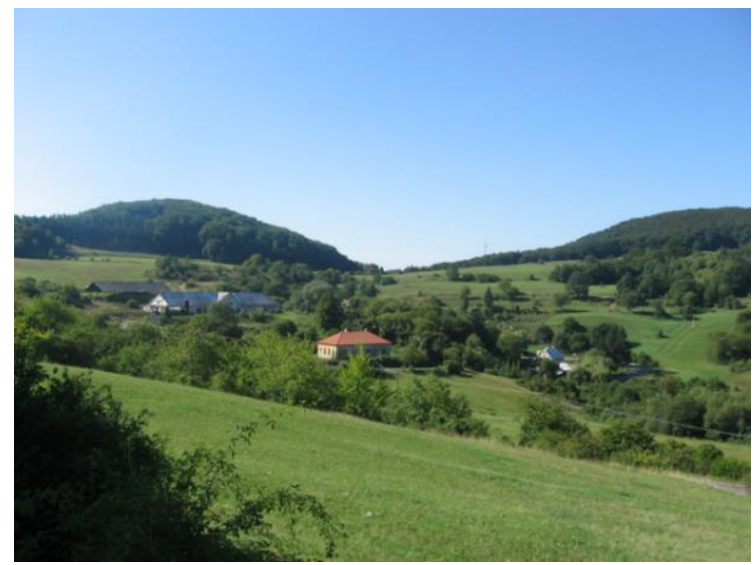

Fig 2. Radobica - Cerová štál

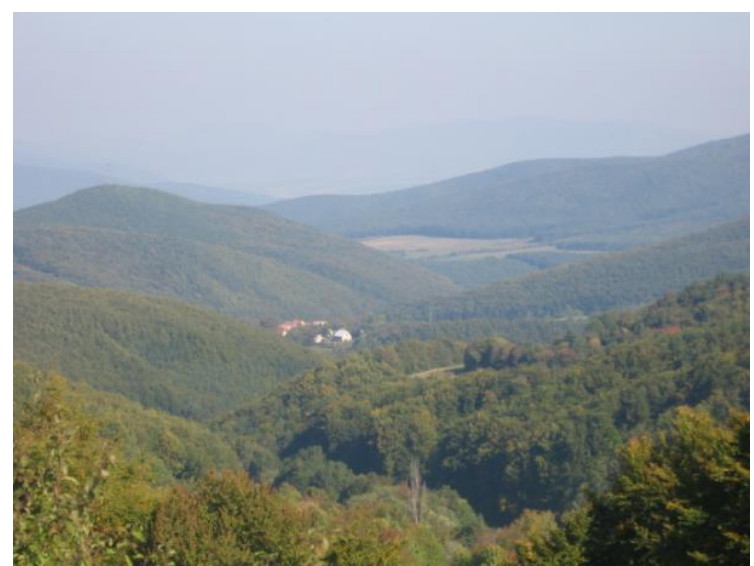

Fig 4. Vel'ké Pole - Tomov štál

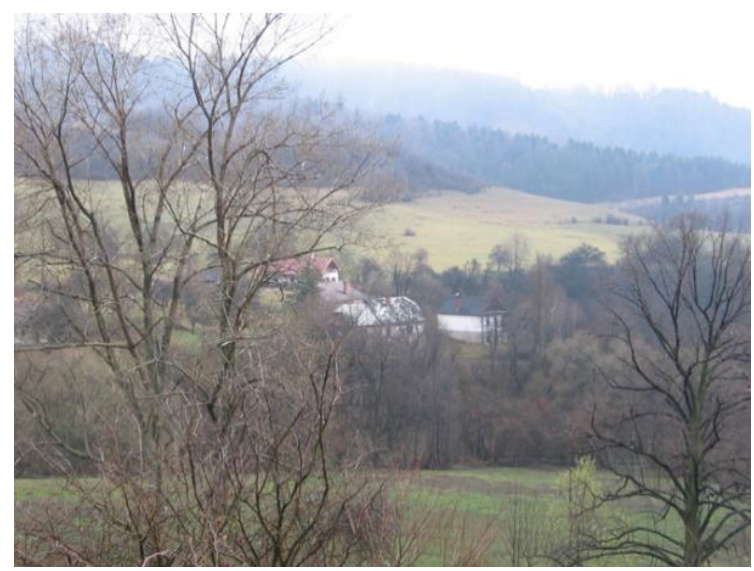

Fig 6. Velké Pole - Horný Francov štál 


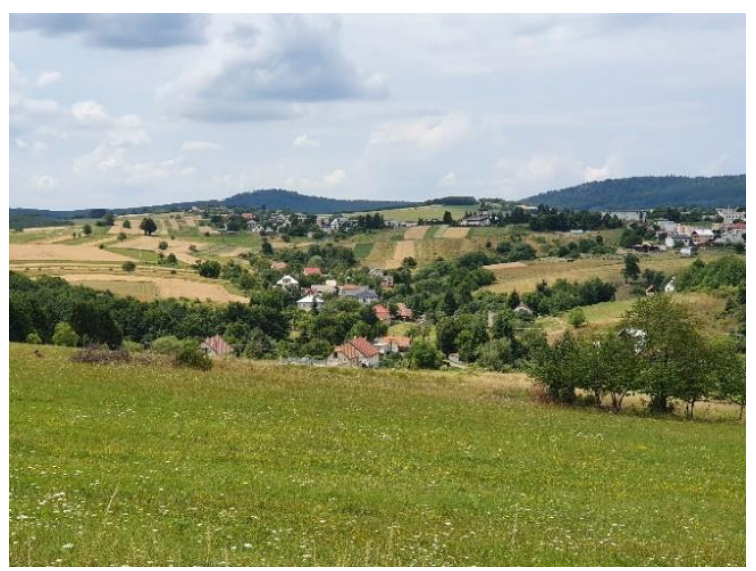

Fig 7. Malá Lehota - Šmykniarov štál

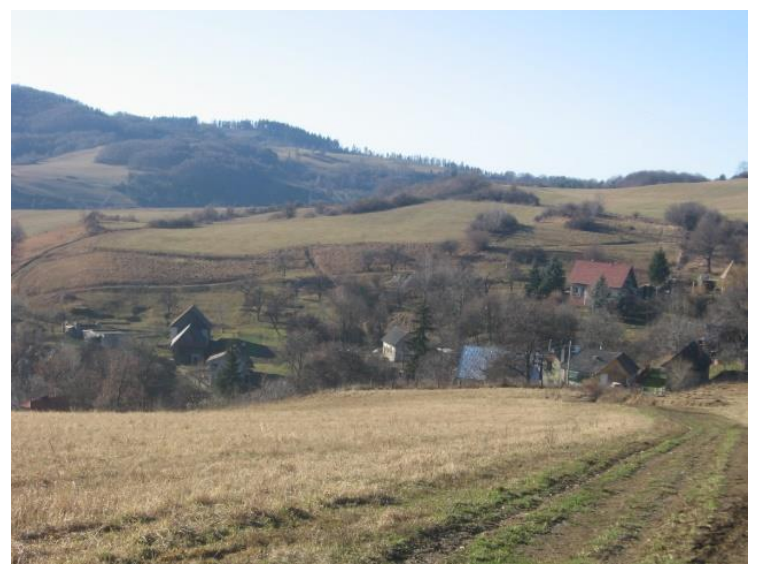

Fig 9. Velké Pole - Gregerov štál

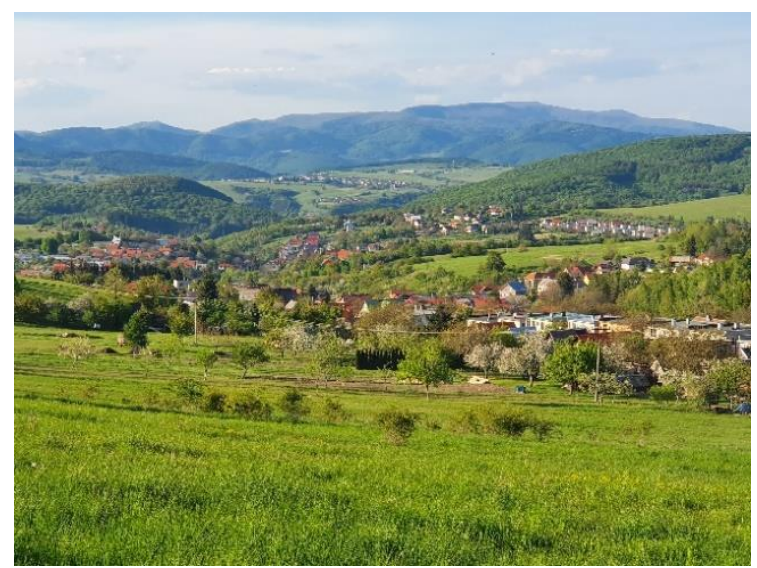

Fig 8. View from Vel'ká Lehota to Malá Lehota

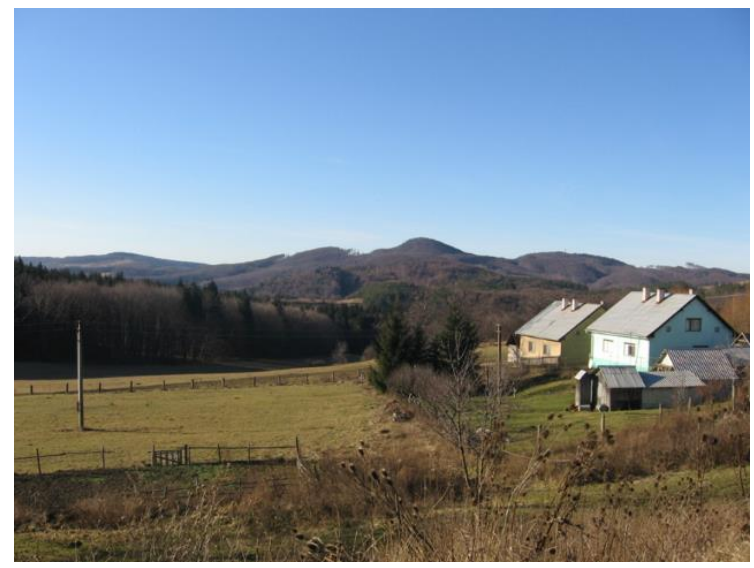

Fig 10. Vel'ké Pole - Penhübel

\section{Method}

We carried out the research in several steps. Individual „kopanice“ was verified by direct mapping in the field. The research included direct interviews with residents and a questionnaire survey. The next step was the interpretation of landscape changes based on historical, topographic maps and orthophoto maps. Data from all time horizons were processed by using ArcGIS 9.1 A detailed description is part of the chapter, which deals with the analysis of landscape changes.

\subsection{Novobanská štálová area}

Dispersed settlements in this area arose mainly in connection with mining, woodcutting, coal mining and pastoralism. Dispersed settlement is characterized by two decisive features - it occurs in mountainous areas (most often at altitudes of 500-800 m above sea level), which are in some ways marginal and are formed by dispersed groups of economic settlements that create special, economic and social structures of the population. Novobanská štálová area includes 14 municipalities stretching from Nová Baňa to the north and the northwest, covering the districts of Žarnovica, Zlaté Moravce and Prievidza on area of $314 \mathrm{~km}^{2}$. Each of these districts is located in a different region. The district of Žarnovica belongs to the Banská Bystrica region, the district of Zlaté Moravce to the Nitra region and the district of Prievidza to the Trenčín region. Novobanská Štalová area border can not therefore be linked to administrative borders, because dispersed settlement crosses Nová Baňa as the region Pohronie. Novobanská Štálová area is located at the contact of the Tribeč, Pohronský Inovec and Vtáčnik mts.

Except Nová Baňa as a city, where we primarily monitor dispersed settlements, the following municipalities belong to this area: Revišské Podzámčie (part of Žarnovica), Vel'ká Lehota, Malá Lehota, Horné Hámre, Jedlové Kostolany, Vel'ké Pole, Píla, Župkov, Hrabičov, Horná Ves, Radobica, Oslany a Čereňany (Fig. 11). 
The term „štále“ is defined by Stránska (1966) in connection with the terminology of the Central Slovak German population, which came here in the 14th century during the development of mining. German immigrants called their seasonal residences "Staude", and the Slovak „štále“ were initially only a seasonal temporary settlement.

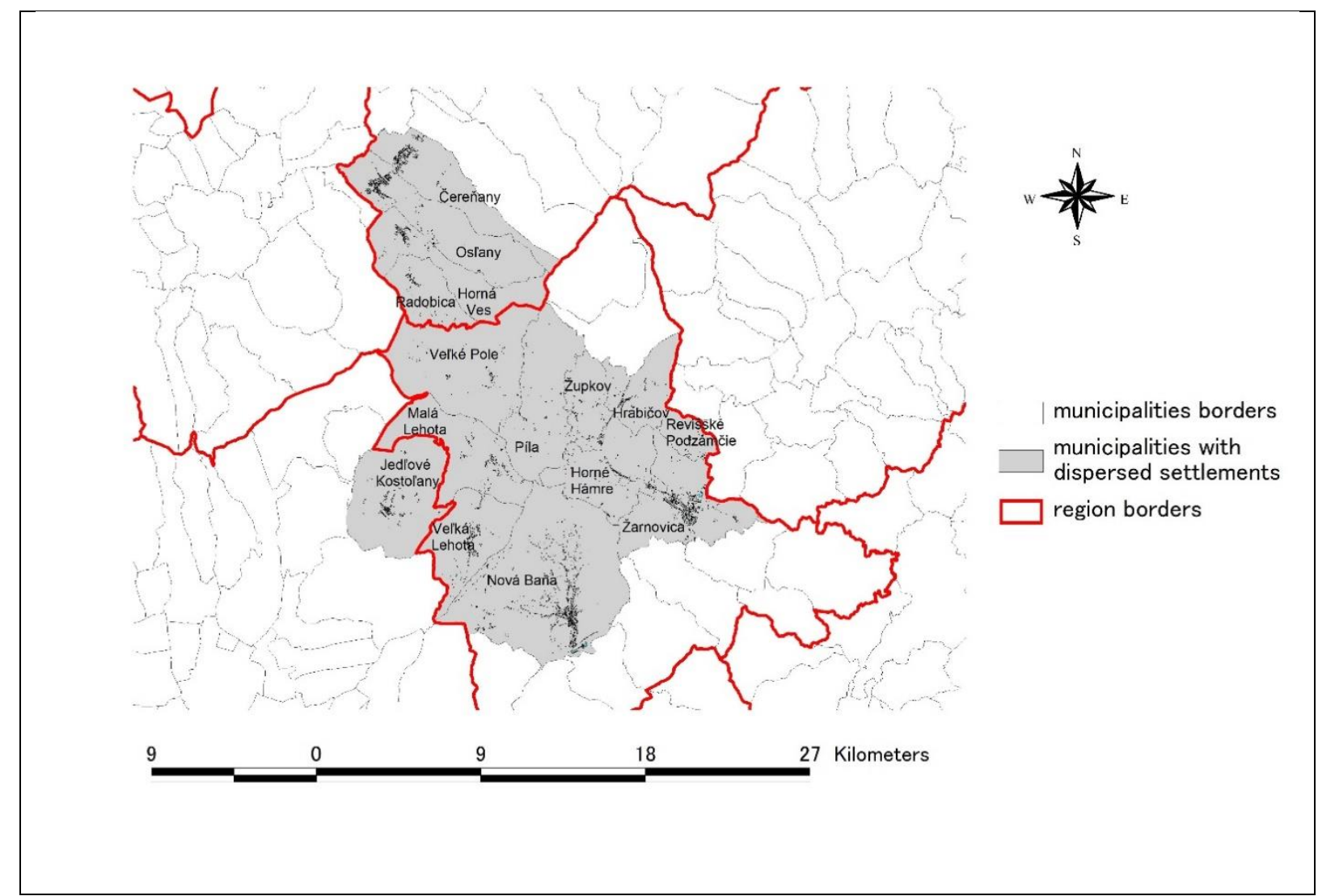

Fig 11. Study area. Source: ArcGIS 9.1

\subsection{Data sources}

The work of Nahálek et al. (1966) was used as the basic material for information about the permanent settlement from 1961, which so far is the only one to comprehensively map the situation of dispersed settlements in Slovakia. The current situation (2018) was mapped by demanding field research, consultations at the municipal offices, as well as behavioral research in the form of questionnaires. A big problem with the data on dispersed settlements is that in the censuses the individual dispersed parts - „kopanice (štále)“, did not act as basic settlement units, then they were administratively connected and thus data on the number of inhabitants of individual „štále“ of the whole village do not exist.

When comparing the records from 1961 and 2006 on the number of štále, inhabitants and houses on štále, we see on them a clear negative tendency of decline or extinction of this type of settlement. Gradually, the primary residential and agricultural function of the štále is lost and changed to recreational. This development is noticeable especially when comparing the number of inhabitants of dispersed settlements. While the total population of these municipalities decreased by $11.53 \%$ (Table 1 ), this decrease was as much as $70.87 \%$ and on the contrary, the centers of these municipalities increased by $42.48 \%$ of the population compared to 1961 . However, such a sharp decrease is not affected by the disappearance of štále, as compared to 1961, the number of stále decreased by only 5 to 169. In accordance with the methodology of 1961, štále with 1 house are not included in this value (currently there are 28 of them registered), as these were included among solitudes (Tab. 2). Even 30 of šále (17.75\%) out of a total of 169 have no permanent residents, and this trend is likely to increase, as 26 of štále (15.38\%) have 1 permanent resident and 17 of štále $(10.05 \%)$ have only 2 permanent residents. Thus, it 
can be assumed that in about 5 years more than $40 \%$ of the current settlements of the Novobanská Štálová area without permanent residents will be transformed into recreation. The total average number of inhabitants in the Novobanská area is $12.8 \%$ of the population of municipalities. On average, štále in Novobanská area are smaller in size, up to $44.97 \%$ (76 of šále) have only 2 to 5 houses, on the contrary, only $16.56 \%$ of štále are made up of more than 20 houses. The number of štále varies in individual municipalities, the lowest number of 1 šál is set aside by the municipality of Oslany, on the contrary, the highest municipality of Horné Hámre are 35 of štále and the town of Nová Baňa are 31 of šále. A big problem in obtaining statistical indicators is the ambiguous allocation of some šále, resp. classification of houses in exposed positions to individual styles. Some of štále is able to be identified by name, only the oldest residents, and it occurred to more confusion. The problem is a simple statistical survey because the individual šále was not managed as the basic statistical unit they are combined and their exact expression requires relatively demanding and lengthy field work.

Tab 1. Basic data on the Novobanská Štálová area. Source: own data elaboration

\begin{tabular}{|c|c|c|c|c|c|c|c|}
\hline & $\begin{array}{c}\text { Number of } \\
\text { inhabitants }\end{array}$ & Density/km² & $\begin{array}{c}\text { Number of } \\
\text { inhabitants } \\
\text { in centre }\end{array}$ & $\begin{array}{c}\text { Number of } \\
\text { štále }\end{array}$ & $\begin{array}{c}\text { Number of } \\
\text { inhabitants } \\
\text { on štále }\end{array}$ & $\begin{array}{c}\text { population share } \\
\text { in municipal } \\
\text { centers (\%) }\end{array}$ & $\begin{array}{c}\text { population } \\
\text { share in šále } \\
(\%)\end{array}$ \\
\hline 1.3 .1961 & 20,846 & 66.4 & 12,755 & 174 & 8,091 & 61.2 & 38.8 \\
\hline 30.6 .2006 & 18,442 & 58.8 & 16,123 & 169 & 2,357 & 87.2 & 12.8 \\
\hline $\begin{array}{c}\text { difference } \\
\text { (in \%) }\end{array}$ & -11.53 & -11.53 & 26.41 & -3.00 & -70.87 & 42.48 & -67.01 \\
\hline
\end{tabular}

Tab 2. The structure of the Novobanská Štálová area according to the number and size of štále in individual municipalities. Source: own data elaboration

\begin{tabular}{|l|c|c|c|c|c|c|c|}
\hline municipality & $\begin{array}{c}\text { solitude (1 } \\
\text { house) }\end{array}$ & $\begin{array}{c}\text { Number of štále } \\
\text { (min. 2 houses) }\end{array}$ & $\begin{array}{c}2-5 \\
\text { houses }\end{array}$ & $\begin{array}{c}6-9 \\
\text { houses }\end{array}$ & $\begin{array}{c}10-19 \\
\text { houses }\end{array}$ & $\begin{array}{c}20 \text { and more } \\
\text { houses }\end{array}$ & $\begin{array}{c}\text { štále without } \\
\text { permanent resident. }\end{array}$ \\
\hline Čereňany & 0 & 2 & 0 & 0 & 1 & 1 & 0 \\
\hline Horná Ves & 1 & 3 & 1 & 0 & 1 & 1 & 1 \\
\hline $\begin{array}{l}\text { Horné } \\
\text { Hámre }\end{array}$ & 6 & 35 & 19 & 9 & 5 & 2 & 5 \\
\hline Hrabičov & 5 & 6 & 2 & 1 & 2 & 0 & 1 \\
\hline $\begin{array}{l}\text { Jedl'ové } \\
\text { Kostol'any }\end{array}$ & 1 & 12 & 2 & 3 & 2 & 5 & 3 \\
\hline Malá Lehota & 0 & 17 & 0 & 4 & 3 & 9 & 0 \\
\hline Nová Baňa & 6 & 31 & 16 & 9 & 3 & 3 & 2 \\
\hline Oslany & 0 & 1 & 0 & & 0 & 1 & 0 \\
\hline Píla & 5 & 22 & 19 & 2 & 1 & 0 & 13 \\
\hline Radobica & 0 & 14 & 3 & 2 & 7 & 2 & 0 \\
\hline $\begin{array}{l}\text { Revišské } \\
\text { Podzámčie }\end{array}$ & 1 & 6 & 4 & 1 & 0 & 1 & 0 \\
\hline $\begin{array}{l}\text { Velká } \\
\text { Lehota }\end{array}$ & 0 & 2 & 0 & 1 & 0 & 1 & 0 \\
\hline Velké Pole & 1 & 11 & 5 & 3 & 3 & 0 & 5 \\
\hline Župkov & 2 & 7 & 5 & 0 & 0 & 2 & 0 \\
\hline Overall & 28 & 169 & 76 & 35 & 28 & 28 & 30 \\
\hline
\end{tabular}

The highest percentage of inhabitants live on štále in Malá Lehota - 63.56\% (including Blažek's štál, which forms the center of the municipality, it is up to $100 \%$ ), Vel'ké Pole $60.11 \%$ and Horné Hámre $57.29 \%$. On the contrary, the lowest number of inhabitants on the šále has the municipality of Čereñany, where they do not make up even $1 \%$ of the population and in the municipalities of Vel'ká Lehota, Horná Ves, Oslany and Nová Baňa they do not reach even $7 \%$ of their population. The low number of inhabitants on šále also affects the use of the housing stock. In 10 of the 14 municipalities is still empty and more than $50 \%$ of houses in 3 villages is 
almost $50 \%$, while the lowest number of empty houses on štále is the town of Nová Baňa $36.08 \%$ (Table 3).

Tab 3. The share of population and empty houses (in \%) of štále and center of individual municipalities. Source: own data elaboration

\begin{tabular}{|l|c|c|c|c|c|c|}
\hline \multirow{2}{*}{} & \multicolumn{2}{|c|}{$\%$ number of inhabitants } & \multicolumn{2}{c|}{$\%$ number of houses } & \multicolumn{2}{c|}{ \% empty houses } \\
\cline { 2 - 8 } & štále & municipality centre štále & municipality centre štále & municipality centre \\
\hline Čereňany & 0.93 & 99.07 & 4.63 & 95.37 & 60.00 & 12.62 \\
\hline Horná Ves & 4.58 & 95.42 & 14.83 & 85.17 & 58.14 & 11.74 \\
\hline Horné Hámre & 57.29 & 42.71 & 68.30 & 31.70 & 49.79 & 21.82 \\
\hline Hrabičov & 13.79 & 86.21 & 36.32 & 63.68 & 49.38 & 0.00 \\
\hline Jedl'ové Kostol'any & 15.93 & 84.07 & 37.79 & 62.21 & 74.06 & 22.92 \\
\hline Malá Lehota* & 63.56 & 36.44 & 76.25 & 23.75 & 47.93 & 25.00 \\
\hline Nová Baňa & 6.05 & 93.95 & 14.23 & 85.77 & 36.08 & 29.93 \\
\hline Oslany & 5.29 & 94.71 & 12.89 & 87.11 & 60.00 & 0.00 \\
\hline Píla & 27.66 & 72.34 & 27.39 & 72.61 & 86.05 & 3.51 \\
\hline Radobica & 43.69 & 56.31 & 21.54 & 78.46 & 77.24 & 6.47 \\
\hline Revišské Podzámčie & 36.36 & 63.64 & 36.84 & 63.16 & 61.90 & 11.11 \\
\hline Vel'ká Lehota & 4.50 & 95.50 & 11.13 & 88.87 & 66.67 & 21.32 \\
\hline Velké Pole & 60.11 & 39.89 & 57.76 & 42.24 & 58.21 & 8.16 \\
\hline Župkov & 11.41 & 88.59 & 24.16 & 75.84 & 56.92 & 6.86 \\
\hline Overall & 12.78 & 87.22 & 25.49 & 74.51 & 56.10 & 16.43 \\
\hline
\end{tabular}

* Blažek's štál in Malá Lehota is considered the center of the municipality

Through research, we also tried to find out the share of unused houses that are used as cottages. Just recreation resp. cottages could help save the region and could be an alternative to developing and maintaining a housing stock of dispersed settlements. However, we encountered a problem in this research, even though we learned after consultations that more than $95 \%$ of empty houses in štále are used as cottages, according to the records of municipal authorities, it is just over $60 \%$. This information is influenced by a different taxation of the cottage compared to the family house and so the statement is very rare.

The aim of the research was to evaluate the historical development of a specific form of settlement in Slovakia. We focus on the evaluation of the historical development of the country in the context of data on settlement (population, houses). The evaluation of individual „štále“ aims to evaluate the future trend and perspectives of the development of dispersed settlements in Slovakia. As „štále" are not a separate settlement unit, it is a problem to statistically evaluate their development. For this reason, it is necessary to address research in municipalities and in the field by direct reconnaissance - mapping. Štále are not conducted separately, either directly in municipalities or on map materials, so it was necessary to deal with direct interviews with residents and questionnaires, as even at municipal offices did not have records of which houses can be included in which „štál".

Another goal is to record this situation, if we have direct inhabitants, as in these parts, the older population predominates and consequently, this historical memory of the territory will be lost.

\subsection{Landscape structure changes}

In six neighboring municipalities of the Novobanská Štálová area - Jedlové Kostol'any, Malá Lehota, Vel'ká Lehota, Radobica, Vel'ké Pole and Píla, we made more detailed research aimed at studying changes in land use in different time horizons.

Through the analysis of historical development and the use of old maps, we can relatively accurately locate areas with persistently low intensity of use and areas or lines that have served as a stabilizing function in the cultural landscape throughout the development. At the same time, 
the analysis of the historical development of the landscape allows to interpret the trend of the development of land use in the future. The spatial database of landscape-ecological conditions, the development of land use and the proposal of its potential use can be used as a practical tool for landscape care.

Obtaining information about landscape changes in a periodically updated database will provide a spatial picture of landscape dynamics. Geographic information systems are a suitable tool for the processing of landscape-ecological works, but it is necessary to keep in mind the errors from the accuracy of the data and the logical integration of the data generated by the superposition.

The analysis of changes and trends in land use indicates the suitability of individual types of landscape-ecological complex for proposals for sustainable land use (Chrastina, 2019, Lieskovský et. al., 2018), but the main factor of land use is man, understanding the relationship between human society and landscape, it will make it possible to accurately predict its further development more and to propose specific care and management measures. Identification of areas with different intensity of change in the observed period (235 years) in terms of forms of land use is an auxiliary tool for economic operators in locating existing and planning new activities in the country. Areas without change of use indicate the degree of preservation and originality of ecosystems, which can be used in revising the boundaries of existing protected areas or in declaring new ones.

In recent decades, the study of land use has been a relatively common topic in historical, geographical and landscape ecological research in the world as well as in Slovakia. Capture historical development can help preserve the cultural landscape that has evolved for decades. Landscape changes evaluation is largely linked to ongoing social processes. These then help to interpret the land use change. Directly in this region, we can identify preserved historical landscape structures.

Historical landscape structures represent a specific, time-limited and spatially constantly decreasing subtype of landscape structures as a whole (Huba et al. 1988). It is the structures of dispersed settlements that belong to the best preserved types.

Currently dispersed settlements remain roughly at its original shape or form, but it does not perform its primary function - residential and agricultural property. The rising trend, especially of cottages, can be an impetus for further development in the studied municipalities.

We interpreted the changes on the basis of historical maps from the I. Austro-Hungarian military mapping (year 1783), from military topographic maps of scale 1:25 000 (year 1957) and topographic maps of scale 1: 10000 (year 1992). In addition to the maps we use the available historical documents and period photographs. A very good basis for refining the elements of the current landscape structure (CLS) were color aerial photographs on a large scale of 1:5 000 (2002 and 2018). When comparing time horizons, we took into account the basic groups of landscape elements.

Data from all time horizons were processed by using GIS - ArcGIS 9.1 and then we compared their area changes. In the landscape, we allocated 8 basic groups of landscape elements at the first level. We divided them into 43 subcategories, landscape elements and these were for a better interpretation divided into 74 individual landscape elements.

By analysis and subsequent comparison of the secondary landscape structure of selected time horizons, we can characterize the changes that occurred between the individual groups of landscape elements in the studied area. The European trend of changes in land use since 1783 is mainly increasing the share of the forest and woody vegetation, as well as the group of elements of permanent grasslands at the expense of mainly groups of agricultural crops, which is confirmed by works by authors from different countries: Pärtela, Mändla, Zobela (1999), Garzia-Ruiza et al. (1996), Bürgi, Turner (2002), Izakovičová (2000), Lipský (2000), Kupková (2001), Brůna, Buchta, Uhlírová, (2002), Olah (2003), Kolejka, Marek (2004), Boltižiar et. al, (2016), Ivanová et. al., (2013), Štefunková et al. (2013), Druga et al. (2015), Opršal et al. (2016), Jedlička et al. (2019), Kolejka et al (2020), Skokanová et al. (2020), Slamová, Belčáková (2019). 


\section{Results}

Table 4 shows population changes. We recorded an increase in municipalities where they built apartment buildings during this period and a decrease in peripheral municipalities with poorer accessibility (or the peripheral part - Reviššské Podzámčie, which is part of Žarnovica). The main decline in the population occured in individual štále at the expense of the municipal centers, where new construction of apartment buildings is taking place. In municipalities, where we saw an increase in population (Horná Ves and Župkov), this is related to the construction of new flats. In Župkov, the mayor also received a subsidy for the construction of new housing units. Construction slows outflow resp. keeps the young population in the area. Oslany village is located on the main route Nováky-Partizánske, which is a big advantage.

Tab 4. Population and the change in individual municipalities. Source: own data elaboration

\begin{tabular}{|l|c|c|c|c|}
\hline \multicolumn{1}{|c|}{ Municipality/number of inhabitans } & 2006 & 2018 & change & change \% \\
\hline Čereňany & 1752 & 1691 & -61 & -3.48 \\
\hline Horná Ves & 1055 & 1452 & 397 & 37.63 \\
\hline Horné Hámre & 667 & 644 & -23 & -3.4 \\
\hline Hrabičov & 625 & 574 & -51 & -8.16 \\
\hline Jedlové Kostol'any & 998 & 908 & -90 & -9.02 \\
\hline Malá Lehota & 999 & 860 & -139 & -13.91 \\
\hline Nová Baňa & 7424 & 7364 & -60 & -0.81 \\
\hline Oslany & 2254 & 2363 & 109 & 4.84 \\
\hline Píla & 147 & 139 & -8 & -5.44 \\
\hline Radobica & 570 & 536 & -34 & -5.96 \\
\hline Revišské Podzámčie/Žarnovica & $39 / 6469$ & $25 / 6284$ & $-14 /-288$ & $-35.89 /-2.86$ \\
\hline Vel'ká Lehota & 1237 & 1090 & -147 & -11.88 \\
\hline Vel'ké Pole & 480 & 400 & -80 & -16.67 \\
\hline Župkov & 727 & 858 & 131 & 18.02 \\
\hline
\end{tabular}

\subsection{Changes in the landscape structure of selected municipalities}

Based on the maps of the historical and current landscape structure, we compared and evaluated the changes that occurred in the studied area in 235 years (1783-1957-2018) (Fig. 1). In each municipality, we found out the share of representation of individual groups of landscape elements in the historical and contemporary landscape structure. At the same time, we found out the shares of areas in the municipalities of the studied area that remained unchanged during the historical development, resp. shares of areas that have changed their function.

A detailed analysis was performed on a sample of neighboring municipalities in order to point out the different development of neighboring municipalities in one region. Although the natural conditions are roughly the same and the settlement development has historically been similar, their current state is completely different. Analysis of landscape structure was carried out in the detailed scale of 1:5000. The results are generalized to groups of elements in order to indicate the degree of threat to individual municipalities, especially the abandonment of arable land and its change to grassland. In more exposed, more distant localities from the center of municipalities, there is an intensive overgrowth of agricultural land. The municipalities selected by us captured all trends and for that reason, we did not analyze other municipalities. We assume that these trends are also reflected in other regions with dispersed settlements and their identification at the local level will help to create an integrated management of the country from the level of state administration and self-government. 


\section{Jedl'ové Kostol'any}

Although the observed period of 235 years (1783-1956-2018) is a long time horizon, we can speak of the cadastre of the Jedlove Kostolany as an area with stable land use (Table 5). This fact is also confirmed by the value of the area of $46.39 \%(1,266.25 \mathrm{ha})$ of the cadastre, which did not change its use during this period. The most stable is the forest and woody vegetation, which remained unchanged in this period on the area of $40.50 \%(1,105.50 \mathrm{ha})$ of the cadastre. Forests have been preserved in the northern, eastern and southern parts of the cadastre of the municipality, in the localities of Včelár, Hradište, Žiare, Brezov vrch and Malá Dubová. The group of elements of permanent grasslands remained unchanged only on a small area of $1.49 \%$ ( $40.75 \mathrm{ha})$ of the cadastre, mainly in the western part of the cadastre in the area of Hlboká valley, but also in the area of Brezova štál and in the valley of Žitava. In a larger area of $4.27 \%$ (116.59 ha) of the cadastral area, especially in the urban center of the municipality, a group of elements of agricultural crops has been stably preserved. Within this group of landscape elements, there were shifts from small-block to large-block farming in the 1950s, and in the opposite direction, although not to such an extent in the 1990s. The group of settlement elements and recreational areas did not change only in the area of $0.12 \%(3.41 \mathrm{ha})$ of the cadastre, while the most stable part of the settlement appears to be the center around the Roman Catholic church and cemetery and the nearest part of the lying Lukáčov štál. More than half of the area of $53.61 \%$ (1463.12 ha) of the cadastre changed its function at least once during the examined period. This area is located mainly in the center of the cadastre of the village or in its western part. The main changes in the landscape took place between the group of elements of permanent grasslands and the forest and woody vegetation, but also between the group of elements of agricultural crops and the group of elements of permanent grasslands. In all three monitored periods, $12.20 \%$ (333.02 ha) of the cadastre area completely changed its function. These are mostly areas around the štál and north of the village center, where the original fields were first grassed and later forested due to succession and human activity.

Tab 5. Changes of land use in the municipality Jedlové Kostol'any in the years 1783-1957-2018. Source: own data elaboration

\begin{tabular}{|l|c|c|c|c|c|c|}
\hline \multirow{2}{*}{ Group of landscape elements of } & \multicolumn{2}{|c|}{ JK 1783} & \multicolumn{2}{c|}{ JK1957 } & \multicolumn{2}{c|}{ JK 2018 } \\
\cline { 2 - 7 } & ha & $\%$ & ha & $\%$ & ha & $\%$ \\
\hline forest and woody vegetation & 1604.67 & 58.80 & 1336.63 & 48.96 & 1782.23 & 65.30 \\
\hline permanent grasslands & 229.43 & 8.41 & 778.18 & 28.51 & 691.89 & 25.35 \\
\hline agricultural crops & 830.76 & 30.44 & 505.27 & 18.51 & 144.51 & 5.29 \\
\hline subsoil and substrate elements & 0.00 & 0.00 & 0.33 & 0.01 & 1.81 & 0.07 \\
\hline watercourses and areas & 11.55 & 0.42 & 10.05 & 0.37 & 8.96 & 0.33 \\
\hline residential elements and recreational areas & 30.63 & 1.12 & 57.01 & 2.09 & 45.95 & 1.68 \\
\hline technical elements & 0.00 & 0.00 & 0.41 & 0.02 & 4.64 & 0.17 \\
\hline transport elements & 22.33 & 0.81 & 41.49 & 1.53 & 49.38 & 1.81 \\
\hline Overall & 2729.37 & 100.00 & 2729.37 & 100.00 & 2729.37 & 100 \\
\hline
\end{tabular}

\section{Malá Lehota}

In Malá Lehota, $38.11 \%$ (870.25 ha) of the cadastre area did not change its function during the researched time horizon of 1873-1956-2018 (Table 6). The forest and woody vegetation remained stable on the area of $40.50 \%$ (1105.50 ha) of the cadastre in the area west of the Dolná Šajba, south of Rajnohov štál, in the area of Sokolec, Lámanín and in the northern part of Hlboká valley. This group of landscape elements remained the most stable, but there was a partial change in species composition, caused by the planting of coniferous monocultures in the originally deciduous areas. The group of elements of permanent grasslands remained preserved in the area south of Sokolec, in the vicinity of Debnárov and Hubačov štál, on an area of $1.38 \%$ (31.49 ha) of the cadastre. These are mostly grasslands with the function of pastures used in the past as meadows. 
With an area of $3.47 \%$ (79.25 ha) of the cadastre, a group of elements of agricultural crops remained unchanged, mainly between the Pavlov, Blažek, Adamec and Zimmerman štál, but also in the vicinity of the Debnárov and Tomov štál. The group of settlement elements and recreational areas with an area of $0.16 \%$ ( $3.70 \mathrm{ha}$ ) of the cadastre speaks of the oldest continuous settlement in the municipality. Such localities include parts of Blažek's, Domček's, Pacalaj's, Adamcov's and Debnárs stands. At least once in the examined periods, $56.88 \%(1298.94 \mathrm{ha})$ of the cadastre, area changed its function, of which the zone with an area of $5.95 \%(135.91 \mathrm{ha})$ of the cadastre changed its function in each monitored period. The tendency of gradual overgrowth resp. changes towards less intensive use can also be seen in this area. The largest change of $7.46 \%$ (170.40 ha) of the cadastral area concerns the change of the group of elements of agricultural crops to the group of elements of permanent grasslands. This trend is also confirmed by other large changes in the area: $7.06 \%$ (161.27 ha) of the cadastral area (mostly around rivers) was transformed from a group of elements of permanent grasslands to a forest and woody vegetation and $7.02 \%$ ( $160.27 \mathrm{ha}$ ) the area of the cadastre changed from a group of elements of agricultural crops to a forest and woody vegetation (surroundings of Sokolec and Vojšín hills). In addition to these changes in the area of $6.33 \%$ (144.58 ha) of the cadastre (around Rajnohov, Debnárov, Pacalaj and Hubačov štál) the opposite situation occurred, when the groups of elements of forest and non-forest woody vegetation changed into a group of elements of permanent grasslands.

Tab 6. Changes of land use in the municipality Malá Lehota in 1783-1957-2018. Source: own data elaboration

\begin{tabular}{|l|c|c|c|c|c|c|}
\hline \multicolumn{1}{|c|}{ Group of landscape elements of } & \multicolumn{2}{c|}{$\mathrm{ML} 1783$} & \multicolumn{2}{c|}{$\mathrm{ML} 1957$} & \multicolumn{2}{c|}{$\mathrm{ML} 2018$} \\
\hline & $\mathrm{ha}$ & $\%$ & $\mathrm{Ha}$ & $\%$ & $\%$ & ha \\
\hline forest and woody vegetation & 1209.11 & 52.96 & 1211.83 & 53.08 & 1345.24 & 58.91 \\
\hline permanent grasslands & 232.84 & 10.2 & 583.76 & 25.56 & 625.69 & 27.40 \\
\hline agricultural crops & 776.46 & 34 & 376.18 & 16.47 & 206.49 & 9.04 \\
\hline subsoil and substrate elements & 0 & 0 & 3.16 & 0.14 & 4.48 & 0.20 \\
\hline watercourses and areas & 7.04 & 0.3 & 10.54 & 0.46 & 10.64 & 0.47 \\
\hline residential elements and recreational areas & 40.67 & 1.78 & 63.37 & 2.77 & 48.93 & 2.14 \\
\hline technical elements & 0 & 0 & 0 & 0 & 4.64 & 0.20 \\
\hline transport elements & 17.51 & 0.76 & 34.79 & 1.52 & 37.52 & 1.64 \\
\hline Overall & 2283.63 & 100 & 2283.63 & 100.00 & 2283.63 & 100.00 \\
\hline
\end{tabular}

\section{Vel'ká Lehota}

In Vel'ká Lehota, the smallest of the studied municipalities remained unchanged for the entire monitored period, with only $36.30 \%$ (675.81 ha) of the cadastre (Table 7$)$. Most of this value consists of a forest and woody vegetation with $30.16 \%$ (561.53 ha) of the cadastre, located mainly in the northern and especially the western part of the cadastre on the border with Jedlové Kostol'any. Forests have been preserved in smaller areas in the southern part of the cadastre, on the border with the Obyce cadastre, in the valley of Osný potok and its tributaries. The group of elements of permanent grasslands did not change in the area of $0.75 \%$ (14.05 ha) of the cadastre in small parts in the urban zone of village and in the area of the Kuchynna hill and south of the Inovec štál.

The group of agricultural crops elements remained unchanged in a larger area of $5.25 \%$ (97.71 ha) of the cadastral area. The elements of this group have been preserved unchanged in the vicinity of the residence, in the vicinity of Kamenný vrch and in the locality of "Červené země" (Red Lands). The territory remained unchanged, the landscape elements were partially transformed from small to large-area. The group of residential elements and recreational areas in all periods remained unchanged on the area of $0.14 \%$ (2.52 ha) of the cadastre in the vicinity of the Roman Catholic Church and in the part where the municipal office is currently located. The trend of gradual growth resp. changes to less intensive use can also be seen in this area, $8.45 \%$ (157.26 ha) of the cadastral area southwest of Vojšín changed from a group of elements 
of agricultural crops to a forest and woody vegetation and $6.0 \%$ (111. $66 \mathrm{ha})$ the area of the cadastre in the area of the Kuchyňa, Kamenný vrch and the Inovec štál has changed from the group of elements of permanent grasslands. Overall, this trend is also supported by the value of the changed area, which represents $63.7 \%$ (675.81 ha) of the cadastre, which is the highest value of the surveyed municipalities. In total, on approximately $11.54 \%$ (214.77 ha) of the cadastral area, there were changes in land use in each of the monitored periods, which was mainly related to the change in management in individual periods.

Tab 7. Changes of land use in the municipality Vel'ká Lehota in 1783-1957-2018. Source: own data elaboration

\begin{tabular}{|l|c|c|c|c|c|c|}
\hline \multicolumn{1}{|c|}{ Group of landscape elements } & \multicolumn{2}{c|}{ VL 1783} & \multicolumn{2}{c|}{ VL1957 } & \multicolumn{2}{c|}{ VL2018 } \\
\hline & ha & $\%$ & ha & $\%$ & ha & $\%$ \\
\hline forest and woody vegetation & 934.86 & 50.22 & 884.13 & 47.49 & 1025.38 & 55.07 \\
\hline permanent grasslands & 143.39 & 7.70 & 561.48 & 30.16 & 503.46 & 27.04 \\
\hline agricultural crops & 724.24 & 38.89 & 348.51 & 18.72 & 235.85 & 12.67 \\
\hline subsoil and substrate elements & 0.00 & 0.00 & 0.24 & 0.01 & 0.38 & 0.02 \\
\hline watercourses and areas & 9.58 & 0.51 & 6.85 & 0.37 & 7.12 & 0.38 \\
\hline $\begin{array}{l}\text { Group of residential elements and recreational } \\
\text { areas }\end{array}$ & 21.32 & 1.15 & 35.15 & 1.89 & 47.97 & 2.58 \\
\hline technical elements & 0.00 & 0.00 & 0.00 & 0.00 & 4.72 & 0.25 \\
\hline transport elements & 28.50 & 1.53 & 25.53 & 1.37 & 37.01 & 1.99 \\
\hline Overall & 1861.89 & 100.00 & 1861.89 & 100.00 & 1861.89 & 100.00 \\
\hline
\end{tabular}

\section{Radobica}

Radobica can also be considered a stable landscape (Table 8), because up to $86.3 \%$ (987.8 ha) of the area did not change its function during the observed period. The group of forest and nonforest woody vegetation did not change on 597.8 ha $(52.2 \%)$. Forest complexes have been preserved in the northern part of the territory in the area of Háj and Prochot, southeast of Rigel, and the preserved forest enclaves are in the southeast tip of the territory with the transition to Vel'ké Pole. The group of elements of permanent grasslands remained unchanged at 248.5 ha $(21.7 \%)$ in the south and southeast of the inner city and mostly along watercourses. A group of agricultural crops (205.8 ha) has been preserved on a relatively large area, with a share of $18.0 \%$ of the municipality. Continuous areas maintained around the urban area in the western part as large-block fields and narrow-band areas in the area of the štál. The group of settlement elements and recreational areas did not change to 24.0 ha $(1.1 \%)$, whereas the center of municipality from the cemetery to the surroundings of the church and the two larger settlements Cerová and Banské appear to be the most stable.

Tab 8. Changes of land use in the municipality Radobica in 1783-1957-2018. Source: own data elaboration

\begin{tabular}{|l|c|c|c|c|c|c|}
\hline \multicolumn{1}{|c|}{ Group of landscape elements } & \multicolumn{2}{c|}{$\mathrm{R} 1783$} & \multicolumn{2}{c|}{$\mathrm{R} 1957$} & \multicolumn{2}{c|}{$\mathrm{R} 2018$} \\
\hline \multicolumn{1}{|c|}{} & $\mathrm{ha}$ & $\%$ & $\mathrm{Ha}$ & $\mathrm{ha}$ & $\%$ & ha \\
\hline forest and woody vegetation & 597.8 & 52.2 & 603.8 & 52.73 & 602.1 & 52.58 \\
\hline permanent grasslands & 317.4 & 27.7 & 192.1 & 16.77 & 248.5 & 21.7 \\
\hline agricultural crops & 205.8 & 18.0 & 312.5 & 27.29 & 221.1 & 19.34 \\
\hline subsoil and substrate elements & - & - & 0.3 & 0.00 & 2.2 & 0.19 \\
\hline watercourses and areas & - & - & - & - & - & - \\
\hline residential elements and recreational areas & 24 & 2.0 & 36.1 & 3.15 & 70.3 & 6.13 \\
\hline technical elements & - & - & 0.2 & 0.0 & 0.8 & 0.06 \\
\hline transport elements & - & - & - & - & - & - \\
\hline Overall & 1145 & 100 & 1145 & 100 & 1145 & 100 \\
\hline
\end{tabular}

Only a small part of the territory changed its function during the monitored period $(13.7 \%-$ 157.2 ha). Substantial changes occurred between the group of elements of agricultural crops and 
the group of permanent grasslands. Overall, we can observe the stabilization of groups of landscape elements, a slight increase of the area of forest complexes and permanent grasslands. The outflow of the young population and the related onset of cottage farming as a primary function.

\section{Píla}

In Píla, land use remained unchanged during the observed period at $45.8 \%,-1,180.2$ ha (Table 9). Of this value, the highest share is again represented by forest areas of 923.9 ha (35.8\%), located mainly on the west of Tabernov rigol and Markov hill, continuous areas are also observed in the north and south of the municipality in the highest positions of Vtáčnik and Tribeč Mts. The group of elements of permanent grasslands remained unchanged at 730.9 ha (28.3\%). Continuous areas are observable southeast of Markov hill, where we observe a gradual change to permanent grasslands with woody plants or succession. Other zones occur in the area of Tabernov rigol, in the southeastern part of the village and are also located along the Pílanský and Čierny streams. The group of agricultural crops remained unchanged at 194.5 ha (7.5\%). Elements of this group remained unchanged in the area of the štál and Hoss's rigol. We observe the change of arable land to permanent grasslands. The group of residential elements and recreational areas remained unchanged on the area of 27.7 ha $(1.1 \%)$. A substantial part of the population is concentrated on the main road and in the center of the municipality, where Roman Catholic church, a municipal office and a primary school are located. Overall, we notice a trend of stabilization of a forest and woody vegetation, as well as a group of permanent grasslands, a change of the primary function of štále to recreational, minimal job opportunities and displacement of young people to surrounding larger cities.

Tab 9. Changes of land use in the municipality Pila in 1783-1957-2018. Source: own data elaboration

\begin{tabular}{|l|c|c|c|c|c|c|}
\hline \multicolumn{1}{|c|}{ Group of landscape elements } & \multicolumn{2}{c|}{$\mathrm{P} 1783$} & \multicolumn{2}{c|}{$\mathrm{P} 1957$} & \multicolumn{2}{c|}{$\mathrm{P} 2018$} \\
\hline & ha & $\%$ & ha & ha & $\%$ & ha \\
\hline forest and woody vegetation & 923.9 & 35.8 & 1377.6 & 53.41 & 1532.6 & 59.42 \\
\hline permanent grasslands & 730.9 & 28.3 & 847.5 & 32.86 & 819.0 & 31.78 \\
\hline agricultural crops & 875.3 & 33.9 & 334.6 & 12.97 & 194.5 & 7.54 \\
\hline subsoil and substrate elements & - & - & 0.2 & 0.00 & 1.7 & 0.06 \\
\hline watercourses and areas & - & - & - & - & - & - \\
\hline residential elements and recreational areas & 48.9 & 1.9 & 14.9 & 0.57 & 27.7 & 1.07 \\
\hline technical elements & - & - & 0.6 & 0.0 & 3.5 & 0.13 \\
\hline transport elements & - & - & - & - & - & - \\
\hline Overall & 2579 & 100 & 2579 & 100 & 2579 & 100 \\
\hline
\end{tabular}

\section{Vel'ké Pole}

In the municipality, $52.4 \%$ (1864.7 ha) of the territory did not change during the defined time horizons. The forest and woody vegetation again appears to be the most stable, which has been preserved on 1385.3 ha, which represents $38.9 \%$ of the territory. Continuous preserved forest complexes can be observed in the vicinity of Stráž, Mala Ostrá, Sokolec and northern part of the municipality in the Vtáčnik Mts. The group of elements of permanent grasslands remained preserved on 1041.2 ha, which represents $29.3 \%$ of the total area. These areas are used as pastures and meadows.

The predominant part of the continuous grasslands is located along the Pílanský stream and southeast of Penhýbel. A group of elements of agricultural crops has been stably preserved on a larger area with a share of $6.07 \%(216.4 \mathrm{ha})$, mainly in the vicinity of the urban area, on the štále, along the main road in the direction of Píla - Vel'ké Pole - Radobica. The group of residential elements and recreational areas remained unchanged at only 52.4 ha (1.7\%), the most stable being the continuous central part along the road from the Roman Catholic Church to the south. The displacement of the population in the period after 1945 was caused by a striking decrease in 
the number of inhabitants, the trend of which continues in the form of an outflow of mostly young population. This trend is also related to the smaller number of people living on šále. Less than half of the territory (47.6\%) changed its function on an area of 1697.3 ha (Table 10). Significant changes also occurred between the group of forest and non-forest vegetation and permanent grasslands and between the group of permanent grasslands and the group of agricultural crops. We observe an increase in the area of forest complexes and conversely, a decrease in the area of agricultural crops, a decrease in the number of more distant štále due to the abandonment and overgrowth of these areas. However, the village has high conditions for the development of agritourism and tourism in connection with the natural environment as well as organized events in the surrounding municipalities.

Tab 10. Changes of land use in the municipality Vel'ké Pole in 1783-1957-2018. Source: own data elaboration

\begin{tabular}{|l|c|c|c|c|c|c|}
\hline \multicolumn{1}{|c|}{ Group of landscape elements } & \multicolumn{2}{c|}{ VP 1783} & \multicolumn{2}{c|}{ VP 1957} & \multicolumn{2}{c|}{ VP 2018} \\
\hline & ha & $\%$ & ha & ha & $\%$ & ha \\
\hline forest and woody vegetation & 1385.3 & 38.9 & 1830.9 & 51.40 & 2206.3 & 61.93 \\
\hline permanent grasslands & 1308.9 & 36.7 & 1158.1 & 32.51 & 1041.2 & 29.26 \\
\hline agricultural crops & 810.4 & 22.8 & 526.7 & 14.78 & 216.4 & 6.07 \\
\hline subsoil and substrate elements & - & - & 4.1 & 0.1 & 17.9 & 0.50 \\
\hline watercourses and areas & - & - & 5.7 & 0.2 & 2.9 & 0.08 \\
\hline residential elements and recreational areas & 57.4 & 1.6 & 29.5 & 0.82 & 63.8 & 1.79 \\
\hline technical elements & - & - & 4.0 & 0.1 & 13.5 & 0.37 \\
\hline transport elements & - & - & - & - & - & - \\
\hline Overall & 3,562 & 100 & 3,562 & 100 & 3,562 & 100 \\
\hline
\end{tabular}

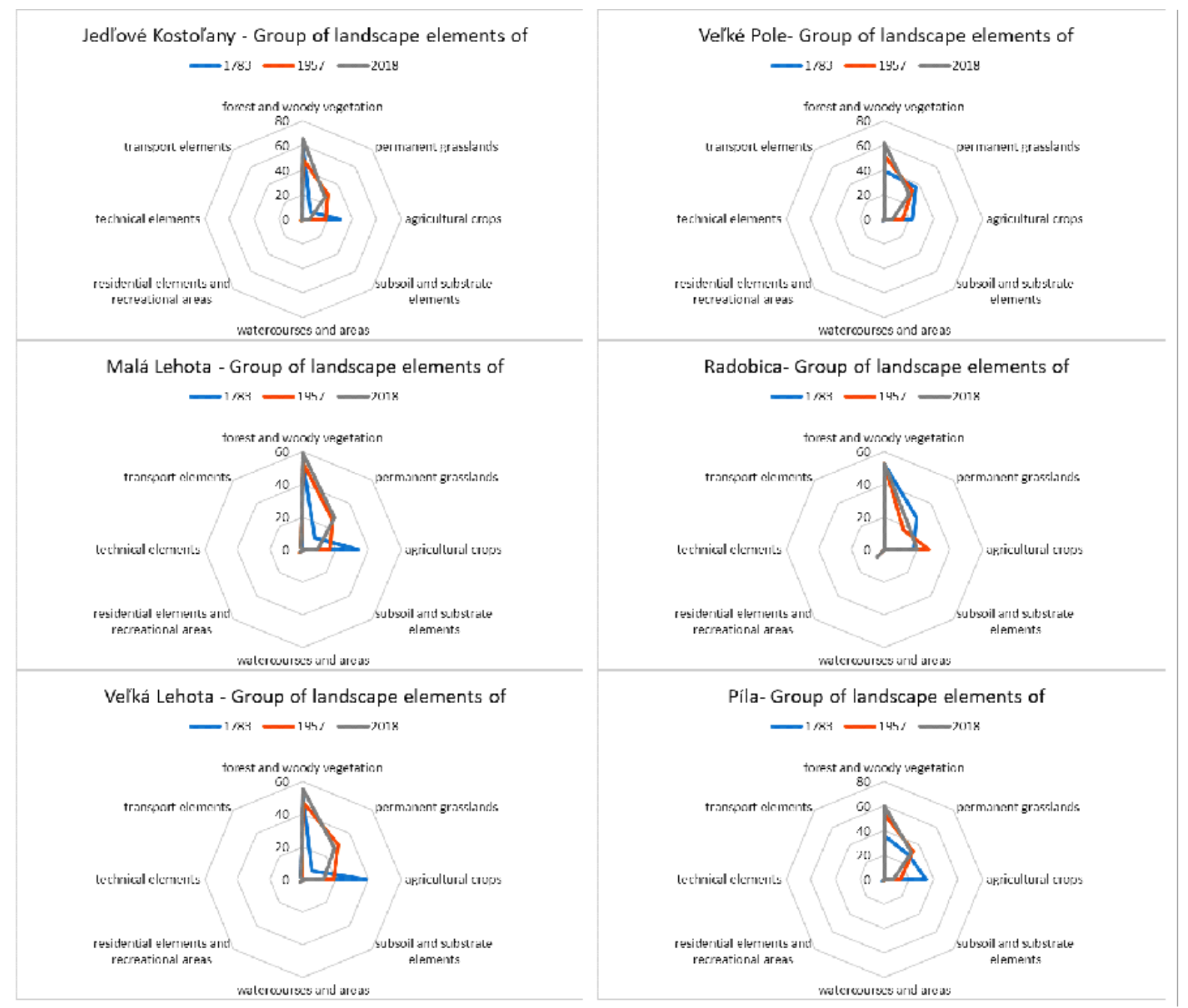

Fig 12. Changes of land use in the municipalities in 1783-1957-2018. Source: own data elaboration 


\subsection{Factors and consequences of landuse changes}

Regions with a dispersed settlement change their appearance and function. The main residentialproduction function is transformed into recreation. This change has been a priority for the last about 30-50 years. The main factors of changes in the use of the land of the monitored municipalities (driving forces of changes in the country) were related to the onset of socialism after World War II, political and economic changes after 1989 and Slovakia's accession to the EU (Bezák, Halada, 2010, Bezák, P., Mitchley, J. 2014, Bezák, Petrovič 2006, Bezák et. al, 2020). Their manifestations and consequences observable in the country are the following:

\section{The onset of socialism}

- establishment of the State Property and the JRD (United Agricultural Cooperative) (1970s)

Consequences for the landscape

- extinction of narrow-band fields and their consolidation into larger blocks - plowing of borders, increase in the share of arable land, shrubs and forests - but not to the same extent as in most regions of Slovakia

- abandoned and overgrown hard-to-reach localities - meadows turn into forest

- intensification of agriculture - increase of production, decrease of agricultural diversity, disappearance of traditional animal husbandry

Political and economic changes after 1989

- the onset of a market economy

- end of state support of agriculture - economic crisis, disintegration of collective forms of management, transformation

- lack of interest of the population in farming

Consequences for the landscape

- a large part of agricultural land is abandoned, grassed and overgrown with shrubs (arable land and permanent grasslands)

- $\quad$ overgrown sidewalks, roads

- displacement of more remote settlements

- change of family houses into cottages

Slovakia's accession to the EU

- $\quad$ pre-accession programs, common agricultural policy, agri-environmental schemes gradual strengthening of agriculture by subsidies - protection and management of grassland habitats, partial management of abandoned localities

- re-emergence of individual forms of management - the onset of extensive forms, increasing the diversity of management

\section{Consequences for the landscape}

- slight increase of grasslands, maintained and managed localities, increase of diversity of landscape elements

- development of seasonal cottages

Then also intensive farming, resulting the disappearance of small structures in the landscape occurred everywhere in Europe, not only in the socialist/communist countries. It was a general process of industrialization of the agriculture, independently from the political regime. The main driving force was the profitability. Communism played a role through subsidizing the crop production in mountainous areas.

The monitored area in the Novobanská štálová area belongs to the interesting areas in terms of human-nature interaction. Although there have also been dynamic changes over the last 50 years, their impact on the landscape and biodiversity has not had such drastic consequences compared to other regions in Slovakia. Manual and at the same time thorough management of 
agricultural land was a phenomenon and therefore displacement and partial abandonment and overgrowth of land is perceived as the biggest obstacle in the development of the territory.

\section{Conclusion and discussion}

The rural agricultural landscape is an important part of our cultural heritage - especially that part of it in which historic landscape structures, traditional or close-to-nature land management, natural and semi-natural types of ecosystems are preserved. In accordance with the European Convention of country, the aim of the Slovak Republic is also to identify and define the types of countries with regard to their special values. As such a specific type of the country of Slovakia that are areas with a dispersed type of settlement. The uniqueness of this type of landscape lies in its limited occurrence. Apart from Slovakia, it occurs only in Czechia, especially on the CzechSlovak border. Because of this fact, which is why we are unique in Europe, we must pay increased attention to this country.

However, the analysis of demographic characteristics of the surveyed municipalities indicates qualitative and quantitative changes leading to the gradual extinction of the territory. The presented area, as a part of the štálová area, has some unique cultural, historical and natural values, which are a reflection of human life and activities in difficult mountain conditions.

The scattered settlement remains roughly in its original form and shape, but no longer fulfills its primary function -habitation. It is mainly the cottage industry that comes to the fore, which could be a spark for further development in the studied municipalities. Cottage housing can be observed here since the early 90 s of the last century, but it has only gained maximum intensity in recent years. This phenomenon is reflected in the number of permanently uninhabited houses, of which more than $4 / 5$ serve as cottages. Favorable location in a tourist-attractive undisturbed landscape, in a mosaic of meadows, pastures and forests, causes an increase of short-term recreation and the subsequent change of the housing fund to cottage housing.

However, in the current development trends, this specific settlement may disappear and therefore it should be given increased attention and seek solutions to preserve these historic landscape structures, which in these regions form the dominant elements of the landscape structure.

According to Ot'ahel, Feranc (1995), the analysis of changes in the country is especially important in terms of assessing natural and socio-economic processes, their dynamics, causes and stability of the current state of interest, but especially possible trends of further development. Any spatiotemporal change in the landscape structure is involved through feedback in influencing the course of mass and energy flows, as well as other properties and characteristics of the landscape (Lipský, 2000). The potential of dispersed settlement is also evaluated in other parts of Slovakia (Petrovič, Muchová 2013, Petrovič et al. 2017), while recently, they appear at thefront of evaluation in the context of cultural ecosystem services (Bezák et al. 2020, Miklos et al. 2020, Špulerová et al. 2018, Vrbičanová et al. 2020).

The aim of the article is to characterize the changes in the country with dispersed settlement. This type of settlement is a specific element of the landscape structure of Slovakia. The character of the origin and development of this specific form of settlement was conditioned by special social and societal conditions. The area of interest consists of the cadastres of the municipalities of Jedl'ové Kostol'any, Malá Lehota, Vel'ká Lehota, Radobica, Píla and Vel'ké Pole. Trends of land use change in the studied region and similarly in Slovakia coincide with development trends in other European countries and are aimed at increasing the area of mainly groups of forest and non-forest woody vegetation at the expense of a group of agricultural crops.

The Kopaničiarska landscape with preserved historical structures, traditional or nature-friendly land management, with the representation of natural and semi-natural types of ecosystems is an important part of our cultural heritage. The landscape as a result of agricultural management is a picture of our attitude to life, the cradle of our culture and an important part of the natural heritage. In this context, we perceive the need to preserve it as a source of identity, historical information about agricultural technologies, customs, traditions, land ownership and land structure as a result of the legal and economic-political conditions of the time. 
Currently, occupying agricultural land fund $49.16 \%$ of Slovakia, traditionally farmed agricultural land accounts for only less than 1\% (Špulerová a kol. 2011). Regularly, managed mosaic form of the $51 \%$, indicating significant trend abandonment of traditional farming (Špulerová, Dobrovodská 2011) and the subsequent rapidly advancing succession of the forest. This represents a serious danger that in the coming years will see an irreversible decline in these high-value landscape structures to be lost. Other factors threatening the traditional way of farming in the country are tourism and construction (Lieskovský et al. 2015) and last but not least a change of requirements on quality of life. The landscape-ecological and cultural-historical significance of a country with dispersed settlements together with their high threat and existential dependence on human agricultural activity are a challenge for us to find a way to preserve them for future generations. It is a space in which landscape ecology, geography, environmental studies, but also history and ethnology, and other scientific disciplines can find a common intersection of their research and significantly enrich the approach to the study of regularities of their development and protection principles.

\section{Acknowledgements}

This research was supported by the project No. 052/2020/OPII/VA „Scientific support of climate change adaptation in agriculture and mitigation of soil degradation" (implemented within the ERDF, Operational Programme Integrated Infrastructure).

\section{Academic references}

[1] Barbes, A. J. \& Robinson, H. A. (1940). A New Method for the Representation of Dispersed Rural Population. Geographical Review 30(1), 134-137.

[2] Belčáková, I., Olah, B., Slámová, M. \& Pšenáková, Z. (2021). A Cultural and Environmental Assessment of a Landscape Archetype with Dispersed Settlements in Čadca Cadastral District, Slovakia. Sustainability 13(3), art. 1200. DOI: 10.3390/su13031200.

[3] Bezák, P. \& Halada, L. (2010). Sustainable management recommendations to reduce the loss of agricultural biodiversity in the mountain regions of NE Slovakia. Mountain Research and Development, 30(3), 192-204. DOI: 10.1659/MRD-JOURNAL-D-10-00023.1.

[4] Bezák, P., Mederly, P., Izakovičová, Z., Moyzeová, M. \& Bezáková, M. (2020). Perception of ecosystem services in constituting multi-functional landscapes in Slovakia. Land, 9(6), 195. DOI: $10.3390 /$ land9060195.

[5] Bezák, P. \& Mitchley, J. (2014). Drivers of change in mountain farming in Slovakia: From socialist collectivisation to the Common Agricultural Policy. Regional Environmental Change, 14(4), 1343-1356. DOI: 10.1007/s10113-013-0580-x.

[6] Bezák, P. \& Petrovič, F. (2006). Agriculture, landscape, biodiversity: Scenarios and stakeholder perceptions in the Poloniny National Park (NE Slovakia). Ekologia Bratislava, 25(1), 82-93.

[7] Boltižiar, M., Olah, B., Gallay, I. \& Gallayová, Z. (2016). Transformation of the Slovak cultural landscape and its recent trends. In Halada, L'., Bača, A. \& Boltižiar, M., eds., Landscape and landscape ecology: proceedings of the 17th International Symposium on Landscape Ecology (pp. 57-67). Bratislava: Institute of Landscape Ecology SAS.

[8] Brůna, V., Buchta, I. \& Uhlírová, L. (2002). Identifikace historické sítě prvků ekologické stability krajiny na mapách vojenských mapovaní. Ústí nad Labem: J.E. Purkyně University.

[9] Bürgi, M. \& Turner, M. G. (2002). Factors and Processes Shaping Land Cover and Land Cover Changes Along the Wisconsin River. Ecosystems 5(5), 184-201. DOI: 10.1007/s10021-001-0064-6. 
[10] Cojacaru, T. (2014). Valasi na Slovensku a Pol'sku, predbežné úvahy. In: Marza, E., Syrný, M., eds., Valašská kolonizácia na Slovensku a Slovenská kolonizácia v Rumunsku (pp. 20 26). Bratislava: Slovak Academy of Sciences.

[11] Donaldson, S. \& Boshoff, E. (2001). Household linkges in dispersed settlement around Pietersburg and implications for household resources management. Journal of Family Ecology and Consumer Sciences 29, 20-27.

[12] Druga, M., Faltan, V. \& Herichova, M. (2015). The purpose of historical land cover change mapping in the territory of Slovakia in the scale 1:10000 - case study of historical cadastral area of Batizovce. Geographia Cassoviensis, 9(1), 17-34.

[13] Etkind, A. (2013). Internal Colonization. Cambridge, GB: Polity.

[14] Fialová, D. \& Vágner, J. (2014). The owners of second homes as user sof rural space in Czechia. Acta Universitatis Carolinea Geographica, (49)2, 21-28. DOI: 10.14712/23361980.2014.11.

[15] Fialová, D., Kadlecová, V. \& Nožičková, V. (2011). Koncept timesharingu jako alternativa apartmánových rekreačních bytů a „,holandských rekreačních vesnic“? Czech Hospitality and Tourism Papers 7(14), 55-67.

[16] Garzia-Ruiza, J. M., Lasanta, T., Ruiz-Flano, P., Ortigosa, L., White, S., Gonzáles, C. \& Martí. C. (1996). Land-use changes and sustainable development in mountain areas: a case study in the Spanish Pyrenees. Landscape Ecology 11(5), 267-277. DOI: $10.1007 / B F 02059854$.

[17] Hansen, J. CH. (1972). Regional Disparities in Norway with Reference to Marginality. Transactions of the Institute of British Geographers 57, 15-30. DOI: 10.2307/621551.

[18] Hoffman, G. W. (1964). Transformation of Rural Settlement in Bulgaria. Geographical Review 54(1), 45-64. DOI: 10.2307/213029.

[19] Hreško, J., Petrovič, F., Mišovičová, R. (2015). Mountain landscape archetypes of the Western Carpathians (Slovakia). Biodiversity and Conservation. 24(13), 3269-3283. DOI: 10.1007/s10531-015-0969-6.

[20] Hromádka, J. (1943). Všeobecný zemepis Slovenska. Bratislava: Slovenská akadémia vied a umenia.

[21] Huba, M. (1989). O niektorýc\&h otázkach genézy a súčasného kopaničiarskeho osídlenia na území Slovenskej republiky. Geografický časopis 41(2), 138-155.

[22] Huba, M. (1990). O perspektívach kopaničiarskeho osídlenia kopaničiarskej krajiny na území Slovenskej republiky. Geografický časopis 42(2), 113-130.

[23] Chaloupecký, V. (1947). Valaši na Slovensku. Praha: Slovanský ústav.

[24] Chrastina, P., Trojan, J., Župčán, L., Tuska, T. \& Hlásznik, P. P. (2019). Land use ako nástroj revitalizácie krajiny: na príklade slovenskej exklávy Tardoš (Mad'arsko). Geographia Cassoviensis,13(2), 121-140. DOI: 10.33542/GC2019-2-03.

[25] Ivanová, M., Michaeli, E., Boltižiar, M. \& Fazekašová, D. (2013). The analysis of changes ecological stability of landscape in the contrasting region of the mountain range and a lowland. In Ecology, economics, education and Legislation vol.1 (pp. 925-938). DOI:10.5593/SGEM2013/BE5.V1/S20.122. Albena: SGEM.

[26] Izakovičová, Z. (2000). Evaluation of the stress factors in the landscape. Ekológia Bratislava, 19(1), 92-103.

[27] Janšák, Š. (1929). Príspevok k osídleniu Slovenska, Obce a kopanice. Sborník muzeálnej slovenskej spoločnosti 23(3-4), 93-111.

[28] Jedlička, J., Havlíček, M., Dostál, I., Huzlík, J. \& Skokanová, H. (2019). Assessing relationships between land use changes and the development of a road network in DOI: 10.2478/quageo-2019-0003. 
[29] Kolejka, J. \& Marek, D. (2004). Konvergence a divergence vývoje kulturní krajiny v českoněmeckém pomezí na Šumave. Životné prostredie 38(2), 66-71.

[30] Kolejka, J., Krejčí, T. \& Nováková, E. (2020). The Pre-industrial landscape in Moravia. The case study of inventory and analysis of the ancient land use structures in the Czech Republic. Land Use Policy, 97, Art. 104712. DOI: 10.1016/j.landusepol.2020.104712.

[31] Kupková, L. (2001). Data o krajině včera i dnes. Geolnfo 1, 16-19.

[32] Lauko, V. (1985). Vývoj a transformácia kopaničiarskeho osídlenia Myjavskej pahorkatiny. Acta FRNUC, Geographica 25, 35-52.

[33] Lauko, V. (1990). Socioekonomický vývoj a charakteristika kopaničiarskeho regiónu Myjavskej pahorkatiny. Acta FRNUC, Geographica 28, 207-221.

[34] The Hodonín region (Czech Republic). Quaestiones Geographicae, 38(1), 145-159.

[35] Lieskovský, J., Kaim, D., Balász, P., Boltižiar, M., Chmiel, M., Grabska, E., Király, G., Konkoly-Gyuró, E., Kozak, J., Antalová, K., Kuchma, T., Mackovčin, P., Mojses, M., Munteanu, C., Ostafin, K., Ostapowicz, K., Shandra, O., Stych, P. \& Radeloff, V. C. (2018). Historical land use dataset of the Carpathian region (1819-1980). Journal of Maps, 14(2), 644-651. DOI: 10.1080/17445647.2018.1502099.

[36] Lieskovský, J., Bezák, P., Špulerová, J., Lieskovský, T., Koleda, P., Dobrovodská, M. Bürgi, M. \& Gimmi, U. (2015). The abandonment of traditional agricultural landscape in Slovakia analysis of extent and driving forces. Journal of Rural Studies, 37, 75-84. DOI: 10.1016/j.jrurstud.2014.12.007.

[37] Lipský, Z. (2000). Sledování změn v kulturní krajině. Kostelec nad Černými lesy: Lesnická práce.

[38] Löw, J. \& Míchal, I. (2003). Krajinný ráz. Kostelec nad Černými lesy: Lesnická práce.

[39] Miklós, L., Izakovičova, Z. \& Špinerová, A. (2016). The Boundaries in the landscape. In Social Geographical Challenges and Search for Adequate Answers in East-Central Europe of the 21st Century, Berehovo: Ferenc Rákoczi II. Transcarpathian Hungarian Institute, pp. 362-371, ISBN 978-617-7404-01-8.

[40] Miklós, L., Špinerová, A., Belčáková, I., Offertálerová, M. \& Miklósová, V. (2020). Ecosystem services: The landscape-ecological base and examples. Sustainability 12(23), Art. 10167. DOI: 10.3390/su122310167.

[41] Nahálka, P., Sitár, E., Mesároš, J., Bizubová, B., Krišták, J., Hlísta, E. \& Holúbek, Š. (1966). Výskum rozptýleného osídlenia na Slovensku. Bratislava: Slovenská vysoká škola technická.

[42] Pärtela, M., Mändla, R. \& Zobela, M. (1999). Landscape history of calcareolus (alvar) grasslands in Hanila, western Estonia, during the last three hundred years. Landscape Ecology 14(2), 129-132. DOI: 10.1023/A:1008040114832.

[43] Norling, G. (1960). Abandonment of Rural Settlement in Västerbotten Lappmark, North Sweden, 1930-1960. Geografiska Annaler 42(4), 232-243. DOI: $10.1080 / 20014422.1960 .11880948$.

[44] Olah, B. (2003). Potential for the sustainable land use of the cultural landscape based on its historical use (a model study of the transition zone of the Polana Biosphere Reserve). Ekológia 22, 79-91.

[45] Olah, B., Boltižiar, M. \& Gallay, I. (2009). Transformation of the Slovak Cultural Landscape Since the 18th Cent. and its Recent Trends. Journal of Landscape Ecology 2(2), 41-55. DOI: 10.2478/v10285-012-0018-z.

[46] Opršal, Z., Kladivo, P. \& Machar, I. (2016). The role of selected biophysical factors in longterm land-use change of cultural landscape. Applied Ecology and Environmental Research, 14(2), 23-40. DOI: 10.15666/aeer/1402_023040. 
[47] Ot’ahel', J. \& Feranec, J. (1995). Výskum zmien krajinnej pokrývky pre poznanie vývoja krajiny. Geographia Slovaca 10, 187-190.

[48] Petrovič, F. (2006). Changes of the landscape with dispersed settlement. Ekológia, 25 (SUPPL. 1), 201-211.

[49] Petrovič, F. (2005). Vývoj krajiny voblasti štálového osídlenia Pohronského Inovca a Tribeča. Nitra: Ústav krajinnej ekológie SAV.

[50] Petrovič, F., Muchová, Z. (2013). The potential of the landscape with dispersed settlement (Case Study Čadca Town). In Fialová, J. \& Kubíčková, H., eds., Public Recreation and Landscape Protection - With Man Hand in Hand? (pp. 199-204). Brno: Mendel University.

[51] Petrovič, F., Stránovský, P., Muchová, Z., Falt’an, V., Skokanová, H., Havlíček, M., Gábor, M. \& Špulerová, J. (2017). Landscape-ecological optimization of hydric potential in foothills region with dispersed settlements - a case study of Nová Bošáca, Slovakia. Applied Ecology and Environmental Research 15(1), 379-400. DOI: 10.15666/aeer/1501_379400.

[52] Sitár, E. (1967). Kopaničiarske osídlenie na Slovensku (niektoré otázky súčasného stavu), Vlastivedný časopis 16(3), 125-135.

[53] Sisestean, G. (2012). Romani care s-au stins. Valahii din Carpatii Nordici si romanii din Ungaria. Cluj-Napoca: Academia Română. Centrul de Studii Transilvana.

[54] Skokanová, H., Netopil, P., Havlíček, M. \& Šarapatka, B. (2020). The role of traditional agricultural landscape structures in changes to green infrastructure connectivity. Agriculture, Ecosystems and Environment, 302, Art. 107071. DOI: 10.1016/j.agee.2020.107071.

[55] Slámová, M. \& Belčáková, I. (2019). The role of small farm activities for the sustainable management of agricultural landscapes: Case studies from Europe. Sustainability 11(21), Art. 5966. DOI: 10.3390/su11215966.

[56] Spišiak, P. (1998). Vývoj obyvatel'stva v kopaničiarskom osídlení Slovenska. Geografické informácie, 5, 18-25.

[57] Stone, G. D. (1991). Agricultural Territories in a Dispersed settlement System. Current Antropology 32(3), 343-353.

[58] Šolcová, L. (2008a). Historical development of settlement villages Vel'ké Pole, Píla and Radobica in the Novobanská Štálová area. In Svatoňová, H., ed., Geography in Czechia and Slovakia: Theory and Practice at the Onset of 21st Century (pp. 62-67). Brno: Masaryk University.

[59] Šolcová, L. (2008b). Vznik a vývoj disperzného osídlenia v Novobanskej štálovej oblasti. Geographia Cassoviensis 2(1), 171-175.

[60] Šolcová, L. (2009). Komparácia zmien krajiny obcí Radobica, Vel'ké Pole a Píla v rokoch 1780-2007. Geografické štúdie 13(2), 87-92.

[61] Špulerová, J., Petrovič, F., Mederly, P., Mojses, M. \& Izakovičová, Z. (2018). Contribution of traditional farming to ecosystem services provision: Case studies from Slovakia. Land, 7(2), Art. DOI: 10.3390/land7020074.

[62] Špulerová, J., Dobrovodská, M., Lieskovský, J., Bača A., Halabuk, A., Kohút, F., Mojses, M., Kenderessy, P., Piscová, V., Barančok, P., Gerhátová, K., Krajčí, J. \& Boltižiar, M. (2011). Inventory and classification of historical structures of the agricultural landscape in Slovakia. Ekológia, 30(2), 157-170. DOI: 10.4149/ekol_2011_02_157.

[63] Špulerová, J. \& Dobrovodská, M. (2011). Rozšírenie historických štruktúr pol'nohospodárskej krajiny na Slovensku. In Kontrišová, O., Marušková, A., Vál'ka, J., Kontriš, J. \& Stašiov, S., eds., Monitorovanie a hodnotenie stavu životného prostredia (pp. 65-70). Zvolen: Technická univerzita vo Zvolene.

[64] Št’astná, M., Vaishar, A. (2020). Values of rural landscape: The case study Chlum u Třeboně (Bohemia). Land Use Policy, 97, Art. 104699. DOI: 10.1016/j.landusepol.2020.104699. 
[65] Štefunková, D., Špulerová, J., Dobrovodská, M., Mojses, M. \& Petrovič, F. (2013). Traditional agricultural Landscapes - A model of detailed land use mapping. Tájökológiai Lapok, 11(1), 1-21.

[66] Vágner, J. \& Fialová, D. (2011). Impacts of Second Home Tourism on Shaping Regional Identity in Regions with Significant Recreational Function. Tourism \& Management Studies (1), 285-294.

[67] Vaishar, A. \& Št’astná, M. (2019). Sustainable development of a peripheral mountain region on the state border: Case study of Moravské Kopanice microregion (Moravia). Sustainability, 11(19), Art. 5540. DOI: 10.3390/su11195540.

[68] Vaishar, A., Nosková, H., Nováková, E. (2019). Historický vývoj národnostního osídlení na Tachovsku od druhé světové války [specialized map]. Praha: Institute of Contemporary History CAS.

[69] Vaishar, A., Dvořák, P., Nosková, H. \& Zapletalová, J. (2017). Present consequences of the post-war migration in the Czech borderland for regional development. Quaestiones Geographicae 36(4), 5-15. DOI: 10.1515/quageo-2017-0032.

[70] Varšík, B. (1985). Myjava do roku 1948. In Dugáček, M. \& Gálik, J. eds., Myjava (pp. 30128. Bratislava: Obzor.

[71] Verešík, J. (1974). Vidiecke sídla. In Plesník, P. et al., ed., Slovensko - L'ud 3 (pp. 463-521). Bratislava: Obzor.

[72] Vrbičanová, G., Kaisová, D., Močko, M., Petrovič, F. \& Mederly, P. (2020). Mapping cultural ecosystem services enables better informed nature protection and landscape management. Sustainability, 12(5), Art. 2138. DOI: 10.3390/su12052138.

Other sources

[73] Európsky dohovor o krajine (2020). https://www.minzp.sk/ochrana-prirody/medzinarodnedohovory/europsky-dohovor-krajine-european-landscape-convention/.

[74] Huba, M. a kol. (1988). Historické krajinné štruktúry. In Ochranca prírody, odborná príloha, spravodajca MV SZOPK. Bratislava.

[75] Retrospektivní lexikon obcí Československé Socialistické republiky 1850-1970. Praha: Federální statistický úřad, 1978, 678 s. 